\title{
Vegetal fibers in polymeric composites: a review
}

\author{
Paulo Henrique Fernandes Pereira1*, Morsyleide de Freitas Rosa ${ }^{1}$, Maria Odila Hilário Cioffi², \\ Kelly Cristina Coelho de Carvalho Benini², Andressa Cecília Milanese², \\ Herman Jacobus Cornelis Voorwald ${ }^{2}$ and Daniela Regina Mulinari ${ }^{3}$
}

\author{
${ }^{1}$ Embrapa Agroindústria Tropical, Fortaleza, CE, Brazil \\ ${ }^{2}$ Departamento de Materiais e Tecnologia, Faculdade de Engenharia de Guaratinguetá, \\ Universidade Estadual Paulista - UNESP, Guaratinguetá, SP, Brazil \\ ${ }^{3}$ Centro Universitário de Volta Redonda - UniFOA, Volta Redonda, RJ, Brazil \\ *fernandes_eng@yahoo.com.br
}

\begin{abstract}
The need to develop and commercialize materials containing vegetal fibers has grown in order to reduce environmental impact and reach sustainability. Large amounts of lignocellulosic materials are generated around the world from several human activities. The lignocellulosic materials are composed of cellulose, hemicellulose, lignin, extractives and ashes. Recently these constituents have been used in different applications; in particular, cellulose has been the subject of numerous works on the development of composite materials reinforced with natural fibers. Many studies have led to composite materials reinforced with fibers to improve the mechanical, physical, and thermal properties. Furthermore, lignocellulosic materials have been treated to apply in innovative solutions for efficient and sustainable systems. This paper aims to review the lignocellulosic fibers characteristics, as well as to present their applications as reinforcement in composites of different polymeric matrices.
\end{abstract}

Keywords: thermoplastic composite, thermoset composite, lignocellulosic residues.

\section{Introduction}

Nowadays, as an argument to reduce environmental contamination has increased the human conscientization related to correct disposal of materials, in particular there is an effort to industrial waste reuse and to renewable resources use. Thus, in recent years there has been a growth in the development of materials that meet global trends as economic viability, uses, costs and environmental impact. Numerous experimental studies have appeared with focus on the use of natural fibers as reinforcement in composites with thermoplastic or thermoset polymer matrices ${ }^{[1]}$. A statistical analysis of scientific publications in the area of natural fibers composites with thermoplastic and thermoset matrices employing the Web of Science database of peer-reviewed literature is presented in Figure 1. In this statistical search were found publications referred as technical-scientific articles from January 2000 to May 2014. This review shows that the interest on the development of ecologically viable materials, especially with less environmental impact, with the use of raw materials from natural sources, like the natural fibers, is growing in the last decade and reveals an emerging area of polymeric composites.

This paper presents a comprehensive approach on lignocellulosic fibers as well as on the properties of polymer composites formed with these fibers. Recent publications are considered, along with a brief review on grounds in the chemical composition of lignocellulosic materials and the effect of addition fibers on the mechanical, thermal and physical properties of thermoplastic and thermoset matrices.

\section{Fiber Attributes Affecting Polymer Composite Properties}

\subsection{Source and morphology of the cellulosic fibers}

The traditional source of cellulosic fibers has been wood and, for many countries, this will continue to be the case $\mathrm{e}^{[2]}$. Other large sources are cotton, flax, jute, sisal, curauá, hemp and by products from the cultivation of corn, wheat, rice, sugarcane, pineapple, banana and coconut.

The dimension and arrangement of unit cells in a fiber determine the structure and also influence the fiber properties affecting consequently the polymeric composite properties. The amount of each element as well as morphology and properties of fibers are dependent on the plant species, crop production, place of extraction, plant age, plant part chosen and soil conditions where they were grown ${ }^{[3-6]}$. These variables represent one of the prominent barriers for the large-scale manufacture of lignocellulosic-based composites.

Lignocellulosic fibers are characterized by their cellular structures composed by cells that contains crystalline (highly ordered) and amorphous (disordered) regions interconnected through lignin and hemicellulose fragments ${ }^{[7]}$. These regions do not possess well-defined borders and present a transition from an ordered arrangement of the cellulose chains to amorphous $^{[8]}$.

As shown in Figure 2, vegetal fiber structure is formed by a central channel called as lumen, responsible for water and nutrients transportation, and by the cell wall. The cell wall of each fiber is composed by several layers as followed: 

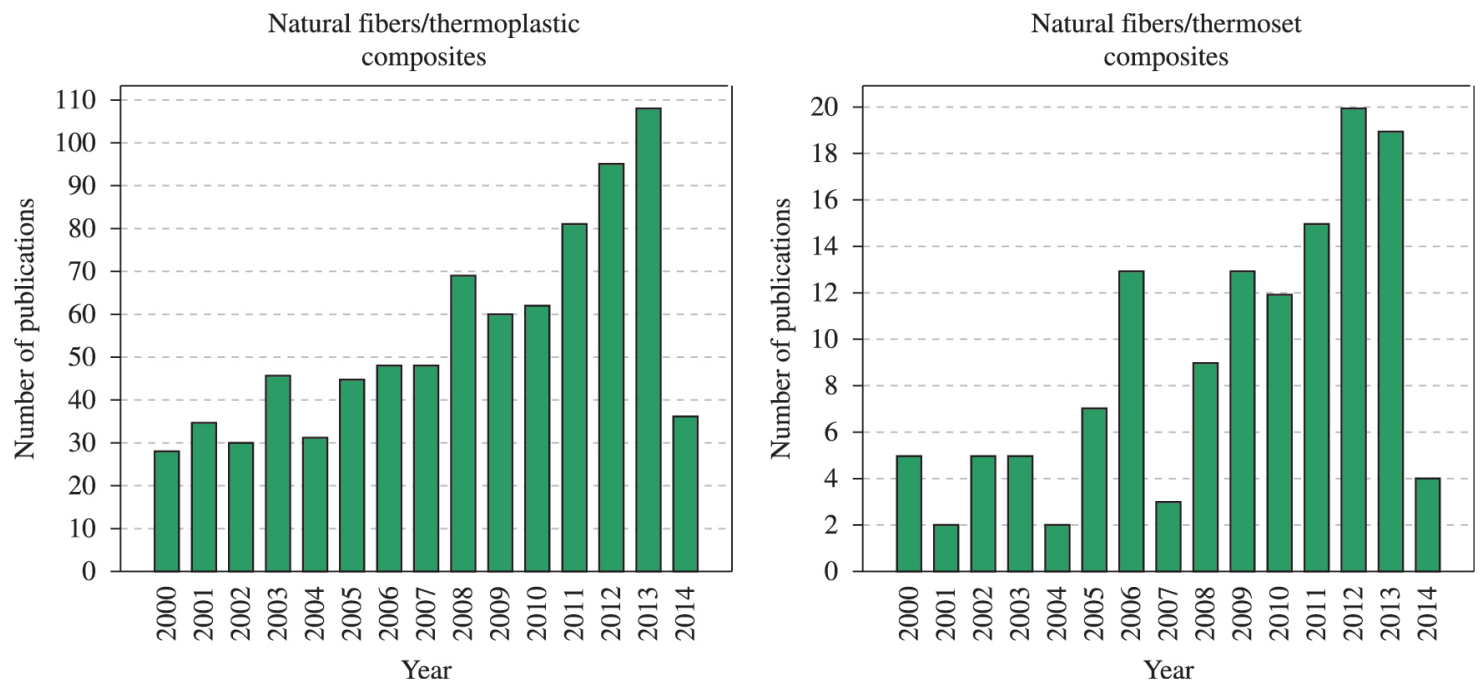

Figure 1. Number of publications about natural fibers composites with thermoplastic and thermoset matrices in the last years from Web of Science database.

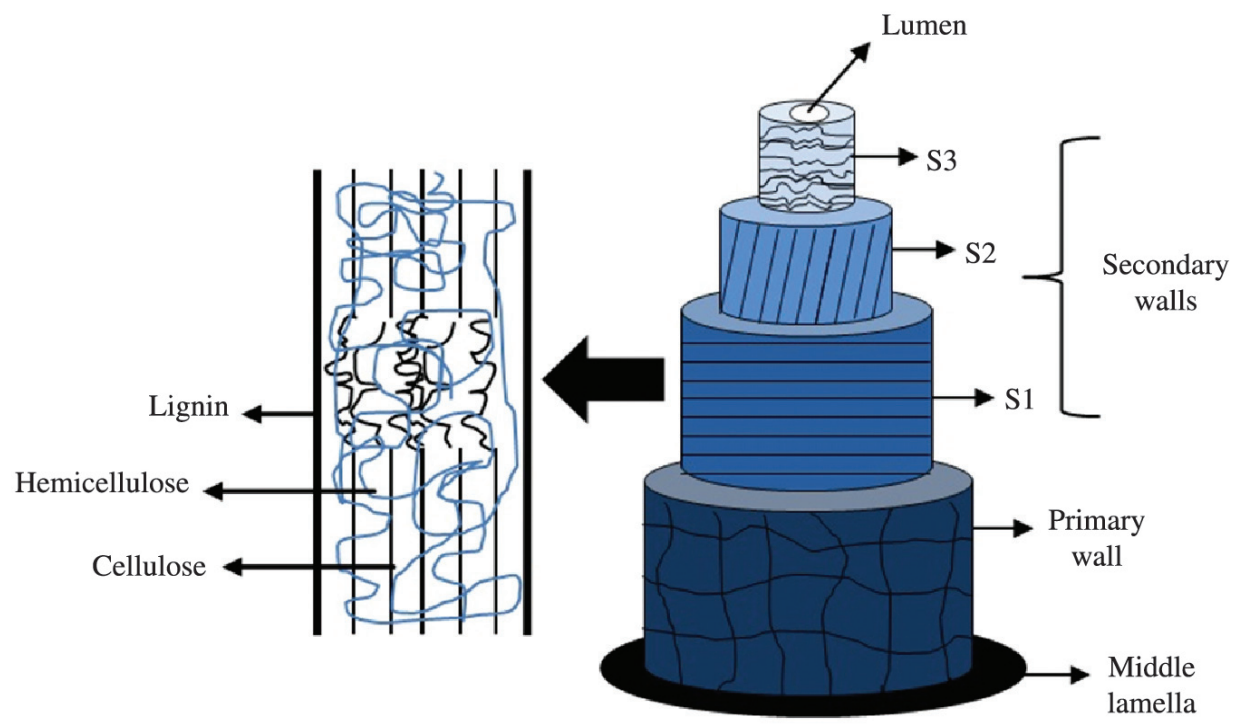

Figure 2. Schematic representation of plant fiber structure: primary wall, middle lamella, lumen, S1 - external secondary wall, S2 - middle secondary wall and S3 -internal secondary wall[10,11].

middle lamella, the thin primary wall, and the secondary wall, which is subdivided into external secondary wall (S1), middle secondary wall (S2) and internal secondary wall (S3). These layers are composed of microfibrils oriented into space in defined (angles) form, according to the each layer ${ }^{[9-12]}$.

The primary wall, initially deposited during the growth of cells, consists in a disordered arrangement of cellulose fibrils placed in a matrix of pectin, hemicellulose, lignin, and protein $^{[10,11]}$. Secondary walls consist of crystalline cellulose microfibrils organized in a spiral arrangement, where the middle layer (S2) determines the fiber mechanical properties. This is consisted by an amount of microfibrils, in a helical conformation of long chains of cellulose. Microfibrils have a diameter of 10 to $30 \mathrm{~nm}$ and are arranged in an amorphous region formed of lignin and hemicellulose, and it is a resulting of a packaging $30-100$ of extended cellulose chain $^{[10,11]}$. The middle lamella, that is outer layer of cell, is composed predominantly by pectin that acts as cement between fibers ${ }^{[11]}$.

The fiber strength can be an important factor in selecting a natural fiber for a specific application. A high aspect ratio (length/width) is very important in cellulose-based fiber composites as it gives an indication of possible strength properties. Fiber dimensions, defects, strength, variability, crystallinity, and structure must be taken into consideration.

\subsection{Chemical composition of the cellulosic fibers}

Vegetable fibers have considerably complex structures, defined by a wide variety of organic compounds such as lignin, hemicellulose, waxes, fatty acids, fats, pectins 
among others, and their properties have been investigated by several researchers ${ }^{[13-22]}$.

Cellulose, hemicellulose and lignin are the three main constituents of vegetable fibers. For this reason, they are also referred to as cellulosic or lignocellulosic fibers. The proportion of these components in a fiber depends on the age, source of the fiber and the extraction conditions used to obtain the fibers. Table 1 provides average values of vegetal fibers properties, including their chemical constituents.

The major component of vegetal fibers is the cellulose, which is a long-chain polysaccharide formed by units of $\beta$-D glucose building blocks that bind together through the connections 1 and 4 carbons $\beta(1 \rightarrow 4)$ glycosidic ${ }^{[58-60]}$.

Meyer and Mark ${ }^{[61]}$ have described cellulose crystal structure initially in 1928. Depending on the crystalline geometry, cellulose is classified as I, II, III, IV and X in all cases, the monomeric unit is repeated approximately every $1.03 \mathrm{~nm}$. The most stable configuration around the link $\beta(1 \rightarrow 4)$ implies in the rotation of $180^{\circ}$ between glucose units by repetitive cellulose unit, which is called as cellobiose. Two adjacent glucose units are linked from the eliminating of one water molecule between its hydroxyl groups, bonded to carbon 1 and 4 . The position $\beta$ of the $\mathrm{OH}$ group requires a rotation of the next glucose unit about the axis $\mathrm{C} 1$ - $\mathrm{C} 4$ of pyranosidic ring ${ }^{[58,62-64]}$.
Hemicellulose is present in all layers of the plant cell wall, however it is concentrated in the primary and secondary layers, where occurs in association with cellulose and lignin ${ }^{[58,63,64]}$.

Lignin is a highly crosslinked molecular complex with amorphous structure and acts as a binder agent between individual fiber cells and the fibrils forming the cell wall ${ }^{[3]}$. Aromatic polymers involve multiple layers of celulose-lignin/hemicelulose and form the composite material constituting of cellulose walls ${ }^{[7]}$. It is basically composed by phenylpropane units in a form of a three-dimensional and amorphous macromolecule ${ }^{[63]}$. The different coupling between the lignin precursors (p-cumarylic alcohols, and coniferyl sinapylic) give rise to various types of linkages between phenylpropane units, the most frequent are $\beta-\mathrm{O}-4$ and $\alpha-\mathrm{O}-4$ (50-65\%), $\beta-1$ (9-15\%), $\beta-5$ (6-15\%), $5-5$ (2-9\%) e $\beta-\beta(2-5 \%)^{[58]}$.

Lignin is also responsible for rigidity property of the plant cell wall and acts as a permanent agent to cells connection, producing an impact and compression resistant structure ${ }^{[62]}$.

\subsection{Surface modification of natural fibers}

Natural fibers are incompatible with the hydrophobic polymer matrix and have a tendency to form aggregates, which affect the quality interface of fiber-matrix. These

Table 1. Chemical constituents and crystallinity index (CI) for a wide variety of fiber types.

\begin{tabular}{|c|c|c|c|c|c|c|c|c|}
\hline \multicolumn{2}{|c|}{ Fiber type } & \multirow{2}{*}{$\begin{array}{c}\begin{array}{c}\text { Density }(\mathbf{g} / \\
\left.\mathbf{c m}^{-3}\right)\end{array} \\
1.3-1.4\end{array}$} & \multirow{2}{*}{$\begin{array}{c}\begin{array}{c}\text { Cellulose } \\
\text { (wt.\%) }\end{array} \\
60\end{array}$} & \multirow{2}{*}{$\begin{array}{c}\text { Hemicellulose } \\
\text { (wt.\%) }\end{array}$} & \multirow{2}{*}{$\begin{array}{c}\begin{array}{c}\text { Lignin } \\
\text { (wt.\%) }\end{array} \\
15.9\end{array}$} & \multirow{2}{*}{$\begin{array}{c}\text { Ashes (wt.\%) } \\
1.0\end{array}$} & \multirow{2}{*}{$\begin{array}{c}\text { CI (\%) } \\
58\end{array}$} & \multirow{2}{*}{$\begin{array}{l}\text { Ref. } \\
{[23-29]}\end{array}$} \\
\hline \multirow{5}{*}{$\begin{array}{l}\text { Bast, } \\
\text { bark or } \\
\text { stem } \\
\text { fibers }\end{array}$} & Jute & & & & & & & \\
\hline & Ramie & 1.5 & $80-85$ & $3-4$ & 0.5 & - & 62.9 & {$[23,27,28,30,31]$} \\
\hline & Kenaf & 1.5 & 72 & 20.3 & 9 & 4.0 & 72.1 & {$[26,27,28,32,33]$} \\
\hline & Flax & 1.5 & 71 & $18.6-20.6$ & 2.2 & - & 86.1 & {$[23,26,27,32,34,35]$} \\
\hline & Hemp & 1.5 & 72 & 10 & 3 & 2.3 & 79.9 & {$[26,27]$} \\
\hline \multirow{7}{*}{ Leaf } & Sisal & 1.5 & $74-75$ & $10-13.9$ & 7.6-7.9 & 0.4 & 72.2 & {$[24,25,27,36,37]$} \\
\hline & Banana & 1.5 & $60-65$ & 6-8 & $5-10$ & 1.2 & 39 & {$[28,36,38]$} \\
\hline & Abaca & 1.5 & $56-63$ & $20-25$ & 7.9 & - & 68.7 & {$[36,39]$} \\
\hline & Raffia & - & 44.6 & 13.5 & 2.7 & - & 64 & [40] \\
\hline & Pineapple & $0.8-1.6$ & 83 & - & 12 & - & 38 & {$[23,25,36,41]$} \\
\hline & Curauá & 1.4 & 70.7 & 21.1 & 7.5 & 0.8 & 75.6 & {$[23,30,42]$} \\
\hline & Piassava & 28,6 & 31.6 & - & 48.4 & - & - & {$[23,43]$} \\
\hline \multirow{6}{*}{$\begin{array}{c}\text { Fruit/ } \\
\text { Seed }\end{array}$} & Kapok & - & 50.7 & 49.3 & 13.4 & - & 35.3 & {$[44,45]$} \\
\hline & Cotton stalk & 1.5 & 50,6 & 28.4 & 23.1 & - & 74 & {$[40]$} \\
\hline & Sleeve & - & 55 & 20.6 & 23.8 & - & - & [46] \\
\hline & Weed & - & 69 & - & 17 & - & 74.1 & {$[47]$} \\
\hline & Luffa cylindrica & 0.82 & 62 & 20 & 11.2 & 0.40 & 59.1 & {$[48,49]$} \\
\hline & Coir & 1.2 & $43-53$ & 14.7 & $38-40$ & & 44 & {$[23,25,26,37,43]$} \\
\hline \multirow{2}{*}{ Wood } & Soft density & - & $30-60$ & $20-30$ & $21-37$ & $\leq 1$ & - & {$[50]$} \\
\hline & Hard density & - & $31-64$ & $25-40$ & $14-34$ & $\leq 1$ & 71.6 & {$\left[{ }^{[50,51]}\right.$} \\
\hline \multirow{4}{*}{ Talus } & Rice straw & - & 43.2 & 31.7 & 16.9 & 9.9 & 77 & {$[32,40,51]$} \\
\hline & Wheat straw & - & 43.2 & 34.1 & 22 & 4.99 & 54.4 & {$[32,51,52,53,54,55]$} \\
\hline & Barley & - & $31-45$ & $14-15$ & $24-29$ & - & - & [56] \\
\hline & Corn straw & - & 39.82 & 23.19 & 11.98 & - & 50.3 & {$[36,51]$} \\
\hline \multirow[b]{2}{*}{ Reed } & Bamboo & $0.6-1.1$ & $33-45$ & 30 & $20-25$ & - & 59.7 & {$[23,25,27,36,39]$} \\
\hline & Bagasse & 1.25 & 69.4 & 21 & 4.4 & 0.6 & 45.2 & $\begin{array}{c}{[30,38,40,} \\
42,54,57]\end{array}$ \\
\hline
\end{tabular}


are hydrophilic fibers and thus exhibit poor resistance to moisture. To eliminate these problem physical and chemical methods can be used to optimize natural fiber interface ${ }^{[1,65-68]}$. These structures contain reactive functional groups that are capable of bonding with reactive groups in the matrix polymer. Thus, modification of natural fibers is attempted to produce fibers hydrophobic in order to improve interfacial adhesion between the fiber and the matrix polymer.

\section{a) Physical methods}

Some physical methods are used to change the properties of the natural fibers such as electric discharge (corona, cold plasma) and corona treatment. This is one of the most techniques for surface oxidation activation of natural fibers, which changes the surface energy of them. The same effects are reached by cold plasma treatment of various fibers ${ }^{[69]}$.

\section{b) Chemical methods}

The different surface modifications of natural fibers such as alkali, acetylation, silane treatment and peroxide treatment with various coupling agents and others have resulted in improving fiber strength, fiber fitness and fiber-matrix adhesion in natural fiber composites ${ }^{[70-74]}$.

Alkali treatment of fibers is the common method to produce high quality fibers ${ }^{[69]}$. In this treatment, parameters as type and concentration of the alkali solution, operational temperature, temperature treatment time, material strength, as well as the applied additives are considered. Various silanes were found to have effectively improved the interface properties of wood-polypropylene, mineral filled elastomers, and fiber reinforced epoxies and phenolics ${ }^{[75]}$

Silanes having reactive alkyl groups bond chemically in order to form adhesives reacting with appropriate groups and thus promote adhesion. Silanes having non-reactive alkyl groups have no chemical coupling activity and, in such cases adhesion appears to arise from improved interfacial compatibility. Silanes have been used to promote adhesion to hydrophilic adherents, such as glass, aluminum, clay, talc, calcium carbonate etc. ${ }^{[76]}$. The silane coupling agents were found to be effective for modified natural fiber-polymer matrix interface. Hashemi et al. ${ }^{[77]}$ investigated polypropylene/bagasse fiber composites prepared by compounding polypropylene (PP) with bagasse fibers as reinforcing filler. Surfaces of fibers were modified through the use of silane coupling agents (Vinyltrimethoxysilane and $\gamma$-Glycidoxypropyltrim ethoxysilane). The fiber coating was performed by mixing of silane with fibers and cured through microwave oven in presence of catalyst. It was found that modification of surface fiber will change the physical, mechanical, morphological, and rheological properties of composite. It was observed from scanning electron microscopy that fiber adhesion to matrix has been improved and so as dispersion. Addition of fibers increases the melt viscosity in unmodified fibers but reduced the melt viscosity for modified fibers and even the viscosity is lower at higher loading compared with unmodified fibers. The tensile strength and tensile modulus increased in modified fibers compared with the unmodified on the same loading, but elongation at break decreased. The effect of coupling agent on properties of filled PP depends on the content of coupling agents and optimum amount was achieved through measurement of water absorption.
Ruggiero et al. ${ }^{[78]}$ analyzed unbleached (SCB) and peroxide bleached (PB-SCB) sugarcane bagasse fibers grafted with hydroxyphenylbenzotriazole UV absorber (1) and/or hindered nitroxide radical of piperidinyloxy type $\mathrm{e}^{[3]}$. PB-SCB fibers were also acetylated with acetic anhydride.

In the recent years, procedures for the modification of metallic oxide coated cellulose fibers, Cell/MxOy, have been studied $^{[79,80]}$. This material type has been used for specific applications: $\mathrm{TiO}_{2}$ for bactericidal activities ${ }^{[81]}, \mathrm{ZrO}_{2}$ for retention and analysis of $\mathrm{Cr}(\mathrm{VI})^{[82]}$, sulphate ${ }^{[83]}$ and $\mathrm{Al}_{2} \mathrm{O}_{3}$ for adsorption of some metal halides from ethanol solution ${ }^{[84]}$.

The experimental methodology of the fibers coating process depends on the form in which the cellulose is obtained, as fiber or membrane. As fiber form, the cellulose treatment with a precursor reagent can be made in aqueous or non-aqueous solvent ${ }^{[85]}$.

Mulinari et al. ${ }^{[86]}$ evaluated the effect of the modification using zirconium oxychloride on cellulose fibers from sugarcane bagasse to reinforce high-density polyethylene in order to improve mechanical properties. Results showed a successfully performance and that the reinforcement of high-density polyethylene presented a tensile strength value higher than that with non-modified cellulose fibers from sugarcane bagasse.

Other type treatment is the delignification, which is generally carried out by extracting using alcohol or benzene reagents and with $\mathrm{NaOH}$ followed by drying at room temperature. Many oxidative bleaching agents such as alkaline calcium or sodium hypochlorite and hydrogen peroxide are commercially used. Bleaching generally results in weight loss and improved tensile strength. Weight losses are mainly attributed to the action of the bleaching agent or alkaline reagent on the noncellulosic constituents of fibers as hemicellulose and lignin ${ }^{[82]}$.

\subsection{Lignocellulosic fibers as reinforcement in composites}

Lignocellulosic fibers are being considered as scientific and technological innovation in the area of new materials, point out the importance of agro waste application, specially, from vegetal fibers as raw material ${ }^{[87]}$. The use, reuse, and recycling of lignocellulosic materials minimize environmental problems and, consequently, improves the health of humanity. It is possible through the use of them, for example, with a propose of reinforce polymer to produce composites, regarding the fact that this fibers have properties such as low cost, low density, biodegradability, recyclability and low abrasiveness, specific mechanical properties capable of improving the mechanical properties of polymeric matrices, flexibility in processing, and the possibility of easily changing its properties through surface treatments ${ }^{[88-92]}$. Another important advantage of the vegetal fiber is strong ecological appeal that comes into your aggregated use, since these fibers can be obtained from industrial waste or simply vegetation considered as invasive with no useful application ${ }^{[93]}$. Synthetic fibers replacement by plant fibers reduce the final cost of material, since with increasing of this type of composite use, the commercialization of vegetal fibers start being made in industrial scale and sustainably ${ }^{[94]}$. 
Vegetal fibers can be used in a wide range of application such as filters for heavy metals retention ${ }^{[86]}$, crafts, and as reinforcement to produce polymer matrix composites ${ }^{[95]}$.

Fibers as reinforcement present some characteristics that will interfere in the final properties of composites. Vegetal fibers, due to hydrophilic characteristic, absorbing large quantities of water and are incompatible with most hydrophobic thermoplastics, such as polypropylene and polyethylene, damaging the interfacing of composite ${ }^{[91,92,96]}$.

In general, for composites reinforced with natural fibers, the surface treatments are used in order to remove amorphous constituents such as hemicellulose and lignin, with the goal of to get as much cellulose as possible with higher levels of crystallinity. Higher mechanical properties and thermal degradation resistance can associate to higher cellulose content at the fiber ${ }^{[91]}$.

Other important characteristic regarding to strengthen a polymer with natural fiber is the thermal degradation of fibers, which is in average around $200^{\circ} \mathrm{C}$, limitant parameter to processing temperature. The fiber size, morphology, and fiber orientation are also characteristics that influence directly the composites final properties ${ }^{[33,97,98]}$.

Composite processing also affects the final properties of materials, thereby obtaining of natural composites requires specific conditions with this respect, in operational processing materials are subject to temperature variations, at shear tension besides to be exposed to oxygen ${ }^{[59]}$.

A great amount of natural fibers have now been studied for applications as reinforcement of composites that use thermoplastic or thermosettings matrices, the most used are sisal, jute, bamboo, curauá, bagasse from sugarcane and green coconut shell fibers ${ }^{[99-115]}$.

Table 2 describes some fibers applied as reinforcement with various thermoplastic and thermoset polymeric matrices.

Besides mentioned fibers, every day new fibers appear as an alternative to produce natural composites, in literature there are studies with palmers fibers ${ }^{[41]}$, wheat straw ${ }^{[117]}$ and rice straw ${ }^{[190]}$, pineapple crown ${ }^{[41]}$, banana pseudostem ${ }^{[186,191]}$, banana pells ${ }^{[95]}$ and many other fibers can be extracted from different regions of the world.

Thermoplastic matrix composites development reinforced with natural fibers have grown in recent years due to favorable environmental aspects and mainly due to its higher mechanical properties when compared to the unreinforced matrix ${ }^{[94]}$.

According to the literature, the most commonly used thermoplastic polymers as matrix for natural composites are those conventional thermoplastics called as commodity, such as polyethylene (PE), high-density polyethylene (HDPE), polypropylene (PP) and polyvinyl chloride (PVC). Other less frequently used polymers are polystyrene (PS) and high impact polystyrene (HIPS) ${ }^{[101,192]}$.

Some of the main properties of thermoplastic polymers commonly used as matrix in natural composites are described in Table 3.

Polyolefin such as polypropylene and polyethylene (low and high density) are polymers originating from unsaturated aliphatic hydrocarbons monomers and present a double reactive carbon-carbon double bond ${ }^{[199]}$.

The polypropylene (PP), a highly crystalline linear chain polymer, due to the mechanical properties, processability, cost, and low process temperature is considered one of the most commonly thermoplastic used as matrix for natural composites $^{[93,99]}$.

Depending upon the density, the polyethylene (low or high) may have a range of properties that vary in agreement with the polymer crystallinity degree, which improves properties such as tensile modulus, yield strength and hardness ${ }^{[199]}$.

Borsoi et al. ${ }^{[200]}$ studied the production and characterization of polystyrene composites reinforced with cotton fibers. Considering the results of tensile and bending tests, the authors concluded that with the addition of $20 \%$ of cotton fibers there was an improvement in composites properties, which was influenced by coupling agent.

Table 2. Thermoplastic and thermoset polymeric composites reinforced with different natural fibers.

\begin{tabular}{|c|c|}
\hline Thermoplastic & Vegetal fibers \\
\hline Polypropylene (PP) & 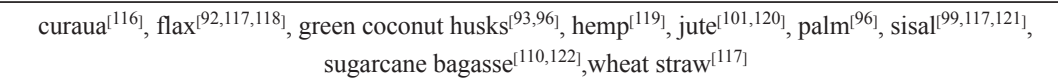 \\
\hline Polyethylene (PE) & banana $^{[123]}$, green coconut husks ${ }^{[124]}$, rice husk ${ }^{[125]}$, sisal $^{[126]}$, sugarcane bagasse ${ }^{[22]}$ \\
\hline High density polyethylene (HDPE) & banana $^{[127]}$, curaua $^{[94,116]}, \operatorname{sisal}^{[102]}$, wood $^{[128]}$ \\
\hline High Impact Polystyrene (HIPS) & green coconut husks $^{[129]}$, sisal ${ }^{[130]}$, sugarcane bagasse ${ }^{[131]}$ \\
\hline Thermoset & Vegetal fibers \\
\hline Polyester & $\begin{array}{c}\text { bamboo }^{[132]}, \text {,banana }^{[133,134]}, \text { coconut }^{[69,135]}, \text { curaua }^{[111,136]}, \text { flax }^{[137,138]}, \text { hemp }^{[139-140]}, \text { jute }^{[141-142]} \text {, } \\
\text { pineapple }^{[143,144]}, \text { sisal }^{[145,146]}, \text { sugarcane bagasse }^{[74,147]}\end{array}$ \\
\hline Polyurethane (PU) & banana ${ }^{[148]}$, coconut $^{[149]}$, curaua ${ }^{[108]}$, sisal $^{[150,151]}$ \\
\hline Epoxy & banana $^{[114,152]}$, coconut ${ }^{[153,154]}$, cotton $^{[155]}$, flax $^{[156-157]}$, hemp $^{[158]}$, juta $^{[159-162]}$, pineapple ${ }^{[163]}$, sisal $^{[164-165]}$ \\
\hline Phenolic & $\operatorname{banana}^{[166,167]}$, flax $^{[168,169]}$, jute $^{[170]}, \operatorname{sisal}^{[171-175]}$ \\
\hline Vinylester & coconut $^{[176]}$, hemp $^{[177,178]}$, jute $^{[179-181]}$, pineapple ${ }^{[182]}$, sisal $^{[183,184]}$ \\
\hline Biodegradable aliphatic polyester & sugarcane bagasse $\mathrm{e}^{[185]}$ \\
\hline Corn starch & banana pseudostem ${ }^{[186]}$, sugarcane bagasse ${ }^{[186]}$, curaua ${ }^{[187]}$ \\
\hline $\mathrm{Starch} / \mathrm{EVOH}$ & coconut $^{[188]}$ \\
\hline Soy protein & $\operatorname{sisal}^{[189]}$ \\
\hline
\end{tabular}


Table 3. Physical and mechanical properties of the major thermoplastic and thermoset polymers used as matrices of natural composites $^{[3,193,194,195-198]}$.

\begin{tabular}{|c|c|c|c|c|c|c|}
\hline \multirow{2}{*}{ Properties } & \multicolumn{6}{|c|}{ Thermoplastic matrix } \\
\hline & PP & PE & HDPE & PS & & PVC \\
\hline Density $\left(\mathrm{g} / \mathrm{cm}^{3}\right)$ & $0.90-0.91$ & $0.91-0.95$ & $0.94-0.97$ & $1.04-1.05$ & & 1.38 \\
\hline Tensile modulus (GPa) & $1.1-1.6$ & $0.3-0.5$ & $0.5-1.1$ & $2.5-3.5$ & & 3.0 \\
\hline Tensile strength (MPa) & $20-40$ & $25-45$ & $30-40$ & $35-60$ & & 53 \\
\hline Melting temperature $\left({ }^{\circ} \mathrm{C}\right)$ & 175 & 115 & 137 & 240 & & 212 \\
\hline \multirow{2}{*}{ Properties } & \multicolumn{6}{|c|}{ Thermoset matrix } \\
\hline & Polyester & Epoxy & Vinyl ester & \multicolumn{3}{|c|}{ Phenolic } \\
\hline Density $\left(\mathrm{g} / \mathrm{cm}^{3}\right)$ & $1.0-1.5$ & $1.1-1.6$ & $1.2-1.4$ & \multicolumn{3}{|c|}{1.29} \\
\hline Tensile modulus (GPa) & $2.0-4.5$ & $3.0-6.0$ & $3.1-3.8$ & \multicolumn{3}{|c|}{$2.8-4.8$} \\
\hline Tensile strength (MPa) & $40-90$ & $28-100$ & $69-86$ & \multicolumn{3}{|c|}{$35-62$} \\
\hline Elongation at break - Tensile mode (\%) & 2.6 & $1-6$ & $4-7$ & \multicolumn{3}{|c|}{$1.5-2$} \\
\hline Compression strength (MPa) & $90-250$ & $100-200$ & 86 & \multicolumn{3}{|c|}{$210-360$} \\
\hline Water Absorption - $24 \mathrm{~h}$ at $20^{\circ} \mathrm{C}(\%)$ & $0.1-0.3$ & $0.1-0.4$ & $0.05-0.6$ & \multicolumn{3}{|c|}{$0.1-0.36$} \\
\hline Cure temperature $\left({ }^{\circ} \mathrm{C}\right)$ & $25-200$ & $25-200$ & $25-150$ & \multicolumn{3}{|c|}{$25-200$} \\
\hline Cost $(\mathrm{US} \$ / \mathrm{kg})$ & $1.50-4.00$ & $3.00-20.00$ & $3.20-6.40$ & \multicolumn{3}{|c|}{$6.50-12.00$} \\
\hline
\end{tabular}

Rosario et al. ${ }^{[99]}$ observed that $30 \%$ of residue sisal fiber into polypropylene (PP) matrix caused a $70 \%$ increase in Young's modulus and $140 \%$ in Izod impact strength, a decreasing in the ultimate tensile strength and the deformation at rupture of $9 \%$ and $198 \%$ respectively, was also observed. According to authors this reduction in ultimate tensile strength can be minimized with a previous treatment of the fiber in order to improve fiber/matrix adhesion. No thermal degradation was observed by thermogravimetric analysis, since stability temperature $\left(240^{\circ} \mathrm{C}\right)$ is significantly higher than the composite process temperature that was $200^{\circ} \mathrm{C}$.

Le Moigne et al. ${ }^{[117]}$ and colleagues evaluated statistically the size and shape distribution of flax, sisal and wheat straw after mixing in polypropylene (PP) composites. The fiber type was an important factor that influenced the size distribution and shape of the fibers after mixing with the polymer. The flax fibers were fractures in the elementary fibers long form ${ }^{[117]}$.

George et al. ${ }^{[101]}$ studied the effect of stearic acid, potassium permanganate $\left(\mathrm{KMnO}_{4}\right)$, toluene diisocyanate, and polypropylene modified with maleic anhydride treatments on the mechanical properties of jute fibers composites processed by hot compression molding. With the addition of $55.89 \mathrm{wt} \%$ of jute the properties in tensile, flexural and impact tests presented a considerably improvement. Considering all treatments, the modification with $\mathrm{KMnO}_{4}$ was the most effective to increasing of tensile (53.06 MPa to $68.26 \mathrm{MPa}$ ) and modulus (2557 MPa to $3278 \mathrm{MPa}$ ) strength properties, in relation to composites with untreated fibers.

The polyvinyl chloride (PVC) is the most important polymer from the class of chlorinated monomers and the second most consumed thermoplastic in the world. The PVC defines a class of polymers with good mechanical properties by high intermolecular forces generated because the polarity of chlorine ${ }^{[20,199]}$. According to Grizzo et al. ${ }^{[201]}$ the main characteristics of PVC is its versatility; thermal, electrical and acoustic insulation; flame propagation; chemical, weathering and creep resistance; recyclability and good processability; and cost/benefit.
The properties study of composites reinforced with natural fibers, considering as parameter: the type of natural fiber used, the fiber surface treatment and composites processing in the final properties of the material, is very important once, depending on the composites class, the material could be used in wide range of application, such as packaging, aerospace, sports, construction, and especially in the automotive industry ${ }^{[89,92]}$.

\section{Lignocellulosic Fibers/Thermoset Matrices Composites}

The main thermoset resins used in the production of composite materials are unsaturated polyesters, vinyl ester, derived esters, phenolic, amino, epoxy and furans ${ }^{[179]}$. The physical and mechanical properties of thermoset resins commonly used are listed in Table 3.

The unsaturated polyesters present a wide range of properties and, consequently applications. This material has as advantages, compared with other thermoset resins, the ability to cure at room temperature, good mechanical properties and transparency, besides being produced on a large scale ${ }^{[179]}$. The use of natural fibers as reinforcement for unsaturated polyester has been widely reported in studies involving the sisal, jute, flax, coconut, banana, pineapple, hemp, curaua and sugarcane bagasse fibers.

Epoxy resins used for high-performance composites have high mechanical strength and environmental degradation resistance and are commonly used in the aerospace and naval industries ${ }^{[3]}$. Epoxy resin reinforced with natural fibers is widespread in works involving sisal, jute, flax, coconut, banana, pineapple, cotton and hemp fibers.

Mohan and Kanny ${ }^{[164]}$ studied sisal/epoxy composites synthesized with the addition, by weight, of nanoclays with $1 \%, 3 \%$ and $5 \%$ concentrations. Authors concluded that the nanoclay can be successfully used as filler, that provides good water barrier properties, improving also the tensile properties with further improvement of wear, Tg and dynamic flexural properties. Results showed tensile strength 
of $45 \mathrm{MPa}, 50 \mathrm{MPa}, 55 \mathrm{MPa}$ and $57 \mathrm{MPa}$ for composites with $0 \%$ (no addition), $1 \%, 3 \%$ and $5 \%$ of nanoclay filled composites, respectively.

The vinyl ester resins combine the excellent characteristics of epoxy resin as chemical, thermal and mechanical resistance with easily processing and fast curing stage observed in the polyesters resin $^{[3]}$.

Rassman et al. ${ }^{[178]}$ compared the mechanical properties (tensile, flexural and impact) and water absorption properties of composites reinforced with hemp (kenaf) fibers produced using three different systems of resin (polyester, vinyl ester and epoxy). Laminates of $15 \%, 22.5 \%$ and $30 \%$ fiber volume fraction were manufactured by resin transfer molding (RTM). As a general conclusion, all mechanical properties increased in agreement with growth of fiber volume for all three resin systems. The laminated hemp/polyester showed good values of modulus and impact resistance, laminates hemp/epoxy showed the highest tensile strength $(30 \%-64.5 \mathrm{MPa})$ and those with hemp/vinyl ester exhibited good absorption characteristics of water. Scanning electron microscopy examinations of impact test specimens show that epoxy laminates failed by fiber fracture, polyester laminates by fiber pullout and vinyl ester one by a combination of pullout and fiber fracture.

Regarding phenolic resin, it was recorded as application mainly when high resistance to fire is required, associated to the fact that this resin maintains its properties at elevated temperatures $^{[3]}$.

The work presented by the authors Barreto et al. ${ }^{[171]}$ show the preparation and characterization of composites of jute/phenolic-based cashew nuts shell liquid. Fibers (bi directional textile) were chemically modified with alkali treatment $(5 \%$ and $10 \% \mathrm{NaOH}$ for $6 \mathrm{~h})$ and then bleached with sodium hypochlorite $\mathrm{NaClO} / \mathrm{H}_{2} 0(1: 1)$ at $60-75^{\circ} \mathrm{C}$ for $4 \mathrm{~h}$. The authors concluded that chemical treatment depends on several variables (reagent concentration, temperature and time), with results affecting directly thermal and mechanical properties, biodegradability and consequently fiber/matrix adhesion. The jute fiber composites showed an improvement of $28 \%$ in their mechanical properties due to chemical treatment with $5 \% \mathrm{NaOH}(23.5 \mathrm{MPa})$ and a decrease of $64 \%$ for the composite treated with $10 \% \mathrm{NaOH}(6.6 \mathrm{MPa})$ when compared with jute/phenolic composite without treatment (18.3 MPa).

Some thermoset resins such as polyurethanes (PU), the bismaleimidas (BMI) and cyanate ester (CE) are less frequently used to composites manufacture with natural fibers $^{[3]}$.

The green composites that use polyurethane resin based on castor oil reinforced by sisal fibers have been studied by Milanese et al. ${ }^{[151]}$; Silva et al. ${ }^{[202]}$; Melo and $\mathrm{Pasa}^{[203]}$, with jute fibers by Neto et al. ${ }^{[22]}$; banana peel fiber by Merlini et al. ${ }^{[148]}$; sugarcane bagasse by Miléo et al. ${ }^{[204]}$, and coconut fibers by Mothé and Araújo ${ }^{[149]}$.

Silva et al. ${ }^{[202]}$ reported the hygroscopic, thermal and mechanical properties of sisal/castor oil PU composites evaluated regard to reinforcement geometry (short fiber, long fiber and woven fabric) and alkaline treatment of fibers with sodium hydroxide solution $(10 \% \mathrm{wt})$ for $1 \mathrm{~h}$.
In general, the alkaline treatment improved quasi-static tensile properties of composites with short fibers randomly oriented (43 $\mathrm{MPa}$ to $46 \mathrm{MPa}$ ) and long aligned sisal fibers (107 MPa to $120 \mathrm{MPa}$ ), whereas a negative effect of the alkaline treatment was observed in the mechanical behavior of bidirectional fabric composite (39 $\mathrm{MPa}$ to $34.5 \mathrm{MPa}$ ).

\section{Conclusions}

1. The use of lignocellulosic fibers has increased with the years, mainly due to environmental aspects and low cost. The range of application of these fibers is large, but they have been highlighted as reinforcements for polymer composites with thermoplastic or thermoset matrices.

2. Vegetal fibers, also called lignocellulosic fibers, are basically composed by lignin, hemicellulose and cellulose, and the amount, morphology and how these constituents are found in the fibers depend on many factors.

3. Thus the study of lignocellulosic fiber reinforced polymer composite focus on understanding the properties of composites according to fiber properties, taking into account parameters such as, the type of fiber reinforcement and matrix content, fiber surface treatments and processing conditions.

4. Depending on the type of polymer matrix, thermoplastic or thermoset, a single fiber may also have a different effect on the final properties of the composites. This study showed therefore a summary of the main results obtained in recent studies using natural composite.

\section{Acknowledgements}

The authors acknowledge the financial support from Fundação Cearense de Apoio ao Desenvolvimento Científico e Tecnológico, process $n^{\circ}$ DCR-0024-00522.01.00/12 and Fundação de Amparo à Pesquisa do Estado de São Paulo (Fapesp), process n ${ }^{\circ}$ 2011/14.153-8.

\section{References}

1. Li, W. Y., Jin, A. X., Liu, C. F., Sun, R. C., Zhang, A. P., \& Kennedy, J. F. (2009). Homogeneous modification of cellulose with succinic anhydride in ionic liquid using 4-dimethylaminopyridine as a catalyst. Carbohydrate Polymers, 78(3), 389-395. http:// dx.doi.org/10.1016/j.carbpol.2009.04.028.

2. Belgacem, M. N., \& Gandini, A. (2011). Monomers, polymers and composites from renewable resources. Oxford: Elsevier.

3. Mohanty, A. K., Misra, M., \& Drzal, L. T. (2005). Natural fibers, biopolymers, and biocomposites. Boca Raton: CRC Press. http://dx.doi.org/10.1201/9780203508206.

4. Wallenberger, F. T., \& Weston, N. (2004). Natural fibers, plastics and composites. Boston: Kluwer Academic Publishers. http:// dx.doi.org/10.1007/978-1-4419-9050-1.

5. Ogeda, T. L., \& Petri, D. F. S. (2010). Hidrólise enzimática de biomassa. Química Nova, 33(7), 1549-1558. http://dx.doi. org/10.1590/S0100-40422010000700023.

6. Faruk, O., Bledzki, A. K., Fink, H. P., \& Sain, M. (2014). Progress report on natural fiber reinforced composites. Macromolecular Materials and Engineering, 299(1), 9-26. http://dx.doi.org/10.1002/mame.201300008. 
7. Klemm, D., Heublein, B., Fink, H. P., \& Bohn, A. (2005). Cellulose: fascinating biopolymer and sustainable raw material. Angewandte Chemie International Edition, 44, 3358-3393.

8. Tasker, S., Badyal, J. P. S., Backson, S. C. E., \& Richards, R. W. (1994). Hydroxyl accessibility in celluloses. Polymer, 35(22), 4717-4721. http://dx.doi.org/10.1016/0032-3861(94)90723-4.

9. Abdul Khalil, H. P. S., Bhat, A. H., \& Ireana Yusra, A. F. (2012). Green composites from sustainable cellulose nanofibrils: a review. Carbohydrate Polymers, 87(2), 963-979. http://dx.doi. org/10.1016/j.carbpol.2011.08.078.

10. Silva, R., Haraguchi, S. K., Muniz, E. C., \& Rubira, A. F. (2009). Aplicações de fibras lignocelulósicas na química de polímeros e em compósitos. Química Nova, 32(3), 661-671. http://dx.doi.org/10.1590/S0100-40422009000300010.

11. Pietak, A., Korte, S., Tan, E., Downard, A., \& Staiger, M. P. (2007). Atomic force microscopy characterization of the surface wettability of natural fibres. Applied Surface Science, 253(7), 3627-3635. http://dx.doi.org/10.1016/j.apsusc.2006.07.082.

12. Carvalho, W., Canilha, L., Ferraz, A., \& Milagres, A. M. F. (2009). Uma visão sobre a estrutura, composição e biodegradação da madeira. Química Nova, 32(8), 2191-2195. http://dx.doi. org/10.1590/S0100-40422009000800033.

13. Harries, H. C. (1978). The evolution, dissemination and classification of Cocos nucifera. Botanical Review, 44(3), 265-319.

14. Satyanarayana, K. G., Pillai, C. K. S., Sukumaran, K., Pillai, S. G. K., Rohatgi, P. K., \& Vijayan, K. (1982). Structure property studies of fibres from various parts of the coconut tree. Journal of Materials Science, 17(8), 2453-2462. http:// dx.doi.org/10.1007/BF00543759.

15. Geethamma, V. G., Thomas Mathew, K. T., Lakshminarayanan, R., \& Thomas, S. (1998). Composite of short coir fibres and natural rubber: effect of chemical modification, loading and orientation of fibre. Polymer, 39(6-7), 1483-1491. http://dx.doi. org/10.1016/S0032-3861(97)00422-9.

16. Mukherjee, P. S., \& Satyanarayana, K. G. J. (1986). An empirical evaluation of structure-property relationships in natural fibres and their fracture behaviour. Materials Science, 21(12), 4162-4168. http://dx.doi.org/10.1007/BF01106524.

17. Mahato, D. N., Mathur, B. K., \& Bhattacherjee, S. J. (1993). Effects of alkali treatment on electrical and spectral properties of coir fibre. Journal of Materials Science Letters, 12(17), 1350. http://dx.doi.org/10.1007/BF00241705.

18. Rowell, R. M., Han, J. S., \& Rowell, J. S. (2000). Characterization and factors affecting fiber properties. In E. Frollini, A. Leão, \& L. H. C. Mattoso (Eds.), Natural polymers and agrofibers composites (pp. 115-134). São Carlos: USP.

19. Silva, G. G., De Souza, D. A., Machado, J. C., \& Hourston, D. J. (2000). Mechanical and thermal characterization of native brazilian coir fiber. Journal of Applied Polymer Science, 76(7), 1197-1206. http://dx.doi.org/10.1002/(SICI)10974628(20000516)76:7<1197::AID-APP23>3.0.CO;2-G.

20. Martins, G. S., Iozzi, M. A., Martins, M. A., Mattoso, L. H. C., \& Ferreira, F. C. (2004). Caracterização mecânica e térmica de compósitos de poli (cloreto de vinila) reforçados com fibras de sisal. Polímeros: Ciência e Tecnologia, 14(5), 326-333. http://dx.doi.org/10.1590/S0104-14282004000500010.

21. Tomczak, F., Sydenstricker, T. H. D., \& Satyanarayana, K. G. (2007). Studies on lignocellulosic fibers of Brazil. Part II: Morphology and properties of Brazilian coconut fibers. Composites Part A: Applied Science and Manufacturing, 38(7), 1710-1721. http://dx.doi.org/10.1016/j.compositesa.2007.02.004.

22. Corradini, E., Ito, E. N., Marconcini, J. M., Rios, C. T., Agnelli, J. A. M., \& Mattoso, L. H. C. (2009). Interfacial behavior of composites of recycled poly(ethyelene terephthalate) and sugarcane bagasse fiber. Polymer Testing, 28(2), 183-187. http://dx.doi.org/10.1016/j.polymertesting.2008.11.014.

23. Hattalli, S., Benaboura, A., Ham-Pichavant, F., Nourmamode, A., \& Castellan, A. (2002). Adding value to Alfa grass (Stipa tenacissima L.) soda lignin as phenolic resins 1. Lignin characterization. Polymer Degradation \& Stability, 76(2), 259-264. http://dx.doi.org/10.1016/S0141-3910(02)00022-8.

24. Leão, A. L., Rowell, R., \& Tavares, N. (1998). Applications of natural fibers in automotive industry in Brazil. In P. N. Prasad, J. E. Mark, S. H. Kandil, \& Z. H. Kaifi (Eds.), Science and technology of polymers and advanced materials (pp. 755-761). New York: Plenum Press.

25. Satyanarayana, K. G., Ravikumar, K. K., Sukumaran, K., Mukherjee, P. S., Pillai, S. G. K., \& Kulkarni, A. G. (1986). Structure and properties of some vegetable fibres. Journal of Materials Science, 21(1), 57-63. http://dx.doi.org/10.1007/ BF01144699.

26. Majeed, K., Jawaid, M., Hassan, A., Abu Bakar, A., Abdul Khalil, H. P. S., Salema, A. A., \& Inuwa, I. (2013). Potential materials for food packaging from nanoclay/natural fibres filled hybrid composites. Materials \& Design, 46, 391-410. http://dx.doi.org/10.1016/j.matdes.2012.10.044.

27. Dicker, M. P. M., Duckworth, P. F., Baker, A. B., Francois, G., Hazzard, M. K., \& Weaver, P. M. (2014). Green composites: A review of material attributes and complementary applications. Composites Part A: Applied Science and Manufacturing, 56, 280-289. http://dx.doi.org/10.1016/j.compositesa.2013.10.014.

28. Sarikanat, M., Seki, Y., Sever, K., \& Durmuşkahya, C. (2014). Determination of properties of Althaea officinalis L. (Marshmallow) fibres as a potential plant fibre in polymeric composite materials. Composites Part B: Engineering, 57, 180-186. http://dx.doi.org/10.1016/j.compositesb.2013.09.041.

29. Saha, P., Manna, S., Chowdhury, S. R., Sen, R., Roy, D., \& Adhikari, B. (2010). Enhancement of tensile strength of lignocellulosic jute fibers by alkali-steam treatment. Bioresource Technology, 101(9), 3182-3187. http://dx.doi.org/10.1016/j. biortech.2009.12.010. PMid:20074944

30. Satyanarayana, K. G., Guimarães, J. L., \& Wypych, F. (2007). Studies on lignocellulosic fibers of Brazil. Part I: source, production, morphology, properties and applications. Composites Part A: Applied Science and Manufacturing, 38(7), 1694-1709. http://dx.doi.org/10.1016/j.compositesa.2007.02.006.

31. Li, X., He, L., Zhou, H., Li, W., \& Zha, W. (2012). Influence of silicone oil modification on properties of ramie fiber reinforced polypropylene composites. Carbohydrate Polymers, 87(3), 2000-2004. http://dx.doi.org/10.1016/j.carbpol.2011.10.023.

32. Faruk, O., Bledzki, A. K., Fink, H. P., \& Sain, M. (2012). Biocomposites reinforced with natural fibers: 2000-2010. Progress in Polymer Science, 37(11), 1552-1596. http://dx.doi. org/10.1016/j.progpolymsci.2012.04.003.

33. Karimi, S., Tahir, P. M., Karimi, A., Dufresne, A., \& Abdulkhani, A. (2014). Kenaf bast cellulosic fibers hierarchy: a comprehensive approach from micro to nano. Carbohydrate Polymers, 101, 878-885. http://dx.doi.org/10.1016/j.carbpol.2013.09.106. PMid:24299851

34. Le Moigne, N., Longerey, M., Taulemesse, J. M., Bénézet, J. C., \& Bergeret, A. (2014). Study of the interface in natural fibres reinforced poly(lactic acid) biocomposites modified by optimized organosilane treatments. Industrial Crops and Products, 52, 481-494. http://dx.doi.org/10.1016/j.indcrop.2013.11.022.

35. Tserki, V., Zafeiropoulos, N. E., Simon, F., \& Panayiotou, C. (2005). A study of the effect of acetylation and propionylation surface treatments on natural fibres. Composites Part A: Applied Science and Manufacturing, 36(8), 1110-1118. http://dx.doi. org/10.1016/j.compositesa.2005.01.004. 
36. Azwa, Z. N., Yousif, B. F., Manalo, A. C., \& Karunasena, W. (2013). A review on the degradability of polymeric composites based on natural fibres. Materials \& Design, 47, 424-442. http://dx.doi.org/10.1016/j.matdes.2012.11.025.

37. Ratna Prasad,A. V., \& Rao, K. M. (2011). Mechanical properties of natural fibre reinforced polyester composites: Jowar, sisal and bamboo. Materials \& Design, 32(8-9), 4658-4663. http:// dx.doi.org/10.1016/j.matdes.2011.03.015.

38. Guimarães, J. L., Frollini, E., Da Silva, C. G., Wypych, F., \& Satyanarayana, K. G. (2009). Characterization of banana, sugarcane bagasse and sponge gourd fibers of Brazil. Crops and Products, 30(3), 407-415. http://dx.doi.org/10.1016/j. indcrop.2009.07.013.

39. Liu, K., Takagi, H., Osugi, R., \& Yang, Z. (2012). Effect of physicochemical structure of natural fiber on transverse thermal conductivity of unidirectional abaca/bamboo fiber composites. Composites Part A: Applied Science and Manufacturing, 43(8), 1234-1241.http://dx.doi.org/10.1016/j.compositesa.2012.02.020.

40. Habibi, Y., El-Zawawy, W. K., Ibrahim, M. M., \& Dufresne, A. (2008). Processing and characterization of reinforced polyethylene composites made with lignocellulosic fibers from Egyptian agro-industrial residues. Composites Science and Technology, 68(7-8), 1877-1885. http://dx.doi.org/10.1016/j. compscitech.2008.01.008.

41. Sipião, B. L. L., Paiva, R. L. M., Goulart, S. A. S., \& Mulinari, D. R. (2011). Effect of chemical modification on mechanical behaviour of polypropylene reinforced pineapple crown fibers composites. Procedia Engineering, 10, 2028-2033. http:// dx.doi.org/10.1016/j.proeng.2011.04.336.

42. Hoareau, W., Trindade, W. G., Siegmund, B., Castellan, A., \& Frollini, E. (2004). Sugar cane bagasse and curaua lignins oxidized by chlorine dioxide and reacted with furfuryl alcohol: characterization and stability. Polymer Degradation \& Stability, 86(3), 567-576. http://dx.doi.org/10.1016/j. polymdegradstab.2004.07.005

43. D’Almedia, J. R. M., Aquino, R. C. M. P., \& Monteiro, S. N. (2006). Tensile mechanical properties, morphological aspects and chemical characterization of piassava (Attalea funifera) fibers. Composites Part A: Applied Science and Manufacturing, 37(9), 1473-1479. http://dx.doi.org/10.1016/j. compositesa.2005.03.035.

44. Wang, J., Zheng, Y., \& Wang, A. (2012). Effect of kapok fiber treated with various solvents on oil absorbency. Industrial Crops and Products, 40, 178-184. http://dx.doi.org/10.1016/j. indcrop.2012.03.002.

45. Tye, Y. Y., Lee, K. T., Wan Abdullah, W. N., \& Leh, C. P. (2013). Potential of Ceiba pentandra (L.) Gaertn. (kapok) fiber as a resource for second generation bioethanol: parametric optimization and comparative study of various pretreatments prior enzymatic saccharification for sugar production. Bioresource Technology, 140, 10-14. http://dx.doi.org/10.1016/j.biortech.2013.04.069. PMid:23672935

46. Elizalde-González, M. P., \& Hernández-Montoya, V. (2007). Characterization of adsorbent materials prepared from avocado kernel seeds: natural, activated and carbonized forms. Biochemical Engineering Journal, 36, 230-238.

47. Henrique, M. A., Silvério, H. A., Flauzino Neto, W. P., \& Pasquini, D. (2013). Valorization of an agro-industrial waste, mango seed, by the extraction and characterization of its cellulose nanocrystals. Journal of Environmental Management, 121, 202-209. http://dx.doi.org/10.1016/j.jenvman.2013.02.054 PMid:23542530

48. Almeida, J. M. R., Boynard, C. A., \& Monteiro, S. N. (2000). Effect of chemical treatments on the surface morphology of sponge gourd (Luffa cylindrica) fibers. In Proceedings from 3rd International Symposium on Natural Polymers and Composites - ISNaPol (pp. 27). São Pedro: Embrapa Instrumentação Agropecuária.

49. Tanobe, V. O. A., Sydenstricker, T. H. D., Munaro, M., \& Amico, S. C. A. (2005). A comprehensive characterization of chemically treated Brazilian sponge-gourds (Luffa cylindrica). Polymer Testing, 24(4), 474-482. http://dx.doi.org/10.1016/j. polymertesting.2004.12.004.

50. Jawaid, M., \& Abdul Khalil, H. P. S. (2011). Cellulosic/ synthetic fibre reinforced polymer hybrid composites: a review. Carbohydrate Polymers, 86(1), 1-18. http://dx.doi. org/10.1016/j.carbpol.2011.04.043.

51. Xu, F., Shi, Y. C., \& Wang, D. (2013). X-ray scattering studies of lignocellulosic biomass: a review. Carbohydrate Polymers, 94(2), 904-917. http://dx.doi.org/10.1016/j.carbpol.2013.02.008. PMid:23544649

52. Alemdar, A., \& Sain, M. (2008). Biocomposites from wheat straw nanofibers: morphology, thermal and mechanical properties. Composites Science and Technology, 68(2), 557-565. http:// dx.doi.org/10.1016/j.compscitech.2007.05.044.

53. Chen, L., Hong, F., Yang, X. X., \& Han, S. F. (2013). Biotransformation of wheat straw to bacterial cellulose and its mechanism. Bioresource Technology, 135, 464-468. http:// dx.doi.org/10.1016/j.biortech.2012.10.029. PMid:23186663

54. Cordeiro, N., Ornelas, M., Ashori, A., Sheshmani, S., \& Norouzi, H. (2012). Investigation on the surface properties of chemically modified natural fibers using inverse gas chromatography. Carbohydrate Polymers, 87(4), 2367-2375. http://dx.doi.org/10.1016/j.carbpol.2011.11.001.

55. Kaushika, A., Singh, M., \& Verma, G. (2010). Green nanocomposites based on thermoplastic starch and steam exploded cellulose nanofibrils from wheat straw. Carbohydrate Polymers, 82(2), 337-345. http://dx.doi.org/10.1016/j.carbpol.2010.04.063.

56. Bledzki, A. K., Mamun, A. A., \& Volk, J. (2010). Barley husk and coconut shell reinforced polypropylene composites: the effect of fibre physical, chemical and surface properties. Composites Science and Technology, 70(5), 840-846. http:// dx.doi.org/10.1016/j.compscitech.2010.01.022.

57. Anselmo Filho, P., \& Bahr, O. (2004). Biomass resources for energy in North-Eastern Brazil. Applied Energy, 77(1), 51-67. http://dx.doi.org/10.1016/S0306-2619(03)00095-3.

58. Fengel, D., \& Wegener, G. (1989). Wood chemistry, ultrastructure, reactions. New York: Walter de Gruyter.

59. Castro, D. O. (2010). Biocompósitos a partir de biopolietileno de alta densidade reforçado por fibras de curauá (Dissertação de Mestrado). Universidade de São Paulo, São Carlos.

60. Hendriks, A. T. W. M., \& Zeeman, G. (2009). Pretreatments to enhance the digestibility of lignocellulosic biomass. Bioresource Technology, 100(1), 10-18. http://dx.doi.org/10.1016/j. biortech.2008.05.027. PMid:18599291

61. Meyer, K. H., \& Mark, H. (1928). Uber den bau des krystallisierten anteils der cellulose. Berichte der Deutschen Chemischen Gesellschaft, 61, 593-614.

62. D’ Almeida, M. L. O. (1998). Celulose e papel: tecnologia de fabricação da pasta celulósica (2nd ed.). São Paulo: SENAI.

63. Rowell, R. M. (2005). Handbook of wood chemistry and wood composites. Bota Raton: CRC.

64. Hon, D. N. S. (1996). Chemical modification of lignocellulosic materials. New York: Marcel Dekker.

65. Troedec, M. L., Sedan, D., Peyrsatout, C., Bonnet, J. P., Smith, A., Guinebretiere, R., Gloaguen, V., \& Krausz, P. (2008). Influence of various chemical treatments on the composition and structure of hemp fibres. Composites Part A: Applied Science and Manufacturing, 39(3), 514-522. http://dx.doi. org/10.1016/j.compositesa.2007.12.001. 
66. Torres, F. G., \& Cubillas, M. L. (2005). Study of the interfacial properties of natural fibre reinforced polyethylene. Polymer Testing, 24(6), 694-698. http://dx.doi.org/10.1016/j. polymertesting.2005.05.004.

67. Joseph, P. V., Joseph, K., Thomas, S., Pillai, C. K. S., Prasad, V. S., Groeninckx, G., \& Sarkissova, M. (2003). The thermal and crystallisation studies of short sisal fibre reinforced polypropylene composites. Composites Part A: Applied Science and Manufacturing, 34(3), 253-266. http://dx.doi.org/10.1016/ S1359-835X(02)00185-9.

68. Araújo, J. R., Waldman, W. R., \& De Paoli, M. A. (2008). Thermal properties of high density polyethylene composites with natural fibres: coupling agent effect. Polymer Degradation \& Stability, 93(10), 1770-1775. http://dx.doi.org/10.1016/j. polymdegradstab.2008.07.021.

69. Mulinari, D. R., Baptista, C. A. R. P., Souza, J. V. C., \& Voorwald, H. J. C. (2011). Mechanical properties of coconut fibers reinforced polyester composites. Procedia Engineering, 10, 2074-2079. http://dx.doi.org/10.1016/j.proeng.2011.04.343.

70. Souza, P. S., Rodrigues, E. F., Prêta, J. M. C., Goulart, S. A. S., \& Mulinari, D. R. (2011). Mechanical properties of HDPE/ textile fibers composites. Procedia Engineering, 10, 2040-2045. http://dx.doi.org/10.1016/j.proeng.2011.04.338.

71. Goulart, S. A. S., Oliveira, T. A., Teixeira, A., Miléo, P. C., \& Mulinari, D. R. (2011). Mechanical behaviour of polypropylene reinforced palm fibers composites. Procedia Engineering, 10, 2034-2039. http://dx.doi.org/10.1016/j.proeng.2011.04.337.

72. Oliveira, T. A., Teixeira, A., Mulinari, D. R., \& Goulart, S. A. S. (2010). Avaliação do uso de agente compatibilizante no comportamento mecânico dos compósitos PEBD reforçados com fibras de coco verde. Cadernos UniFOA, 14, 11-17.

73. Liu, L., Yu, J., Cheng, L., \& Qu, W. (2009a). Mechanical properties of poly(butylene succinate) (PBS) biocomposites reinforced with surface modified jute fibre. Composites Part A: Applied Science and Manufacturing, 40(5), 669-674. http:// dx.doi.org/10.1016/j.compositesa.2009.03.002.

74. Brugnago, R. J., Satyanarayana, K. G., Wypych, F., \& Ramos, L. P. (2011). The effect of steam explosion on the production of sugarcane bagasse/polyester composites. Composites Part A: Applied Science and Manufacturing, 42(4), 364-370. http:// dx.doi.org/10.1016/j.compositesa.2010.12.009.

75. Bailly, M., \& Kontopoulou, M. (2009). Preparation and characterization of thermoplastic olefin/nanosilica composites using a silane-grafted polypropylene matrix. Polymer, 50(11), 2472-2480. http://dx.doi.org/10.1016/j.polymer.2009.03.034.

76. Frollini, E., Leão, A. L., \& Mattoso, L. H. C. (2000). Natural polymers and agrofibers composites. São Carlos: USP.

77. Hashemi, S. A., Arabi, H., \& Mirzaeyan, N. (2007). Surface modification of bagasse fibers by silane coupling agents through microwave oven and its effects on physical, mechanical, and rheological properties of PP bagasse fiber composite. Polymer Composites, 28(6), 713-721. http://dx.doi.org/10.1002/pc.20398.

78. Ruggiero, R., Machado, A. E. H., Hoareau, W., Gardrat, C., Nourmamode, A., Grelier, S., \& Castellan, A. (2006). Photodegradation of sugarcane bagasse fibers: influence of acetylation or grafting UV-absorber and/or hindered nitroxide radical on their photostability. Journal of the Brazilian Chemical Society, 17(4), 763-770. http://dx.doi.org/10.1590/S010350532006000400019 .

79. Marques, P. A. A., Trindade, T., \& Neto, C. P. (2006). Titanium dioxide/cellulose nanocomposites prepared by a controlled hydrolysis method. Composites Science and Technology, 66(7-8), 1038-1044. http://dx.doi.org/10.1016/j.compscitech.2005.07.029.

80. Pavan, F. A., Francisco, M. S. P., Landers, R., \& Gushikem, Y. (2005). Adsorption of phosphoric acid on niobium oxide coated cellulose fiber: preparation, characterization and ion exchange property. Journal Brazilian Society, 16(4), 815-820. http://dx.doi.org/10.1590/S0103-50532005000500021.

81. Daoud, W. A., Xin, J. H., \& Zhang, Y. (2005). Surface functionalization of cellulose fibers with titanium dioxide nanoparticles and their combined bactericidal activities. Surface Science, 599(1-3), 69-75. http://dx.doi.org/10.1016/j. susc.2005.09.038.

82. Mulinari, D. R., \& Da Silva, M. L. C. P. (2008). Adsorption of sulphate ions by modification of sugarcane bagasse cellulose. Carbohydrate Polymers, 74(3), 617-620. http:// dx.doi.org/10.1016/j.carbpol.2008.04.014.

83. Karnitz, O. Jr, Gurgel, L. V. A., Freitas, R. P., \& Gil, L. F. (2009). Adsorption of $\mathrm{Cu}(\mathrm{II}), \mathrm{Cd}(\mathrm{II})$, and $\mathrm{Pb}$ (II) from aqueous single metal solutions by mercerized cellulose and mercerized sugarcane bagasse chemically modified with EDTA dianhydride (EDTAD). Carbohydrate Polymers, 77(3), 643-650. http:// dx.doi.org/10.1016/j.carbpol.2009.02.016.

84. Alfaya, R. V. S., \& Gushikem, Y. (1999). Aluminum oxide coated cellulose fibers modified with n-propylpyridinium chloride silsesquioxane polymer: preparation, characterization, and adsorption of some metal halides from ethanol solution. Journal of Colloid and Interface Science, 213(2), 438-444. http://dx.doi.org/10.1006/jcis.1998.6032. PMid:10222085

85. Esumi, K. (1999). Polymer interfaces and emulsions. New York: Marcel Dekker.

86. Mulinari, D. R., Silva, G. L. J. P., Rodrigues, L. A., \& Silva, M. L. C. P. (2007). Adsorção de íons fosfato nos compósitos celulose/ZrO2.nH2O preparados pelos métodos da precipitação convencional e em solução homogênea. Cerâmica, 53(328), 345-353. http://dx.doi.org/10.1590/S0366-69132007000400003.

87. Satyanarayana, K. G., Arizaga, G. G. C., \& Wypych, F. (2009). Biodegradable composites based on lignocellulosic fibers - an overview. Progress in Polymer Science, 34(9), 982-1021. http:// dx.doi.org/10.1016/j.progpolymsci.2008.12.002.

88. Tita, S. P. S., Paiva, J. M. F., \& Frollini, E. (2002). Resistência ao impacto e outras propriedades de compósitos lignocelulósicos: matrizes termofixas fenólicas reforçadas com fibras de bagaço de cana-de-açúcar. Polímeros: Ciência e Tecnologia, 12(4), 228-239. http://dx.doi.org/10.1590/S0104-14282002000400005.

89. Ku, H., Wang, H., Pattarachaiyakoop, N., \& Trada, M. (2011). A review on the tensile properties of natural fiber reinforced polymer composites. Composites Part B: Engineering, 42(4), 856-873. http://dx.doi.org/10.1016/j.compositesb.2011.01.010.

90. Ghali, L., Aloui, M., Zidi, M., Bendaly, H., M’Sahli, S., \& Sakli, F. (2011). Effect of chemical modification of Luffa cylindrical fibres on the mechanical and hydrothermal behaviours of polyester/luffa composites. BioResources, 6(4), 3836-3849.

91. Arrakhiz, F. Z., Elachaby, M., Bouhfid, R., Vaudreuil, S., Essassi, M., \& Qaiss, A. (2012). Mechanical and thermal properties of polypropylene reinforced with Alfa fiber under different chemical treatment. Materials \& Design, 35, 318-322. http:// dx.doi.org/10.1016/j.matdes.2011.09.023.

92. Le Duc, A., Vergnes, B., \& Budtova, T. (2011). Polypropylene/ natural fibres composites: analysis of fibre dimensions after compounding and observations of fibre rupture by rheo-optics. Composites Part A: Applied Science and Manufacturing, 42(11), 1727-1737. http://dx.doi.org/10.1016/j.compositesa.2011.07.027.

93. Ishizaki, M. H., Visconte, L. L. Y., Furtado, C. R. G., Leite, M. C. A. M., \& Leblanc, J. L. (2006). Caracterização mecânica e morfológica de compósitos de polipropileno e fibras de coco verde: influência do teor de fibra e das condições de mistura. Polímeros: Ciência e Tecnologia, 16(3), 182-186.

94. Araujo, J. R., Mano, B., Teixeira, G. M., Spinacé, M. A. S., \& De Paoli, M. A. (2010). Biomicrofibrilar composites of high density polyethylene reinforced with curauá fibers: Mechanical, interfacial and morphological properties. Composites Science 
and Technology, 70(11), 1637-1644. http://dx.doi.org/10.1016/j. compscitech.2010.06.006.

95. Pereira, P. H. F., Benini, K. C. C. C., Watashi, C. Y., Voorwald, H. J. C., \& Cioffi, M. O. H. (2013). Characterization of High density polyethylene (HDPE) reinforced with banana peel fibers. BioResoures, 8(2), 2351-2365.

96. Haque, M. M., Hasan, M., Islam, M. S., \& Ali, M. E. (2009). Physico-mechanical properties of chemically treated palm and coir fiber reinforced polypropylene composites. Bioresource Technology, 100(20), 4903-4906. http://dx.doi.org/10.1016/j. biortech.2009.04.072. PMid:19477124

97. Morandim-Giannetti, A. A., Agnelli, J. A. M., Lanças, B. Z., Magnabosco, R., Casarin, S. A., \& Bettini, S. H. P. (2012). Lignin as additive in polypropylene/coir composites: Thermal, mechanical and morphological properties. Carbohydrate Polymers, 87(4), 2563-2568. http://dx.doi.org/10.1016/j. carbpol.2011.11.041.

98. Summerscales, J., Dissanayake, N. P. J., Virk, A. S., \& Hall, W. (2010). A review of bast fibres and their composites. Part 1 - Fibres as reinforcements. Composites Part A: Applied Science and Manufacturing, 41(10), 1329-1335. http://dx.doi. org/10.1016/j.compositesa.2010.06.001.

99. Rosário, F., Pachekoski, W. M., Silveira, A. P. J., Santos, S. F., Júnior, H. S., \& Casarin, S. A. (2011). Resíduos de sisal como reforço em compósitos de polipropileno virgem e reciclado. Ciência e Tecnologia, 21(2), 90-97.

100. Fuentes, C. A., Tran, L. Q. N., Van Hellemont, M., Janssens, V., Dupont-Gillain, C., Van Vuure, A. W., \& Verpoest, I. (2013). Effect of physical adhesion on mechanical behaviour of bamboo fibre reinforced thermoplastic composites. Colloids and Surfaces A: Pysicochemical and Engeneering Aspects, 418, 7-15. http://dx.doi.org/10.1016/j.colsurfa.2012.11.018.

101. George, G., Jose, E. T., Jayanarayanan, K., Nagarajan, E. R., Skrifvars, M., \& Joseph, K. (2012). Novel bio-commingled composites based on jute/polypropylene yarns: effect of chemical treatments on the mechanical properties. Composites Part A: Applied Science and Manufacturing, 43(1), 219-230. http://dx.doi.org/10.1016/j.compositesa.2011.10.011.

102. Choudhury, A. (2008). Isothermal crystallization and mechanical behavior of ionomer treated sisal/HDPE composites. Materials Science and Engineering A, 491(1-2), 492-500. http://dx.doi. org/10.1016/j.msea.2008.03.011.

103. Mattoso, L. H. C. (1999). Conferência internacional de compósitos reforçados com fibras vegetais. Polímeros: Ciência e Tecnologia, 9(2), 16. http://dx.doi.org/10.1590/ S0104-14281999000200008.

104. Joseph, K., Medeiros, E. S., \& Carvalho, L. H. (1999). Compósitos de matriz poliéster reforçados por fibras curtas de sisal. Polímeros: Ciência e Tecnologia, 9(4), 136-141. http://dx.doi.org/10.1590/S0104-14281999000400023.

105. Paiva, J. M. F., Silva, S. P., Tanaka, I. A., Trindade, W. G., Angelucci, C. A., \& Frollini, E. (2000). Impact strength of phenolic matrices reinforced with lignocellulosic material. In L. H. C., Mattoso, A. Leão, \& E. Frollini (Eds.), Natural polymers and composite (pp. 460-468). São Carlos: EMBRAPA.

106. Pandey, A., Soccol, C. R., Nigam, P., \& Soccol, V. T. (2000). Biotechnological potential of agro-industrial residues. I: sugarcane bagasse. Bioresource Technology, 74(1), 69-80. http://dx.doi.org/10.1016/S0960-8524(99)00142-X.

107. Mochnacz, S., Amico, S. C., \& Sydenstricker, T. H. D. (2002). Caracterização e modificação superficial de fibras de sisal para utilização em compósitos poliméricos. In: Anais do Congresso em Ciências dos Materiais do Mercosul (pp. 182). Joinville: SULMAT.
108. Mothé, C. G., \& Araújo, C. R. (2004). Caracterização térmica e mecânica de compósitos de poliuretano com fibras de curauá. Polímeros: Ciência e Tecnologia, 14(4), 274-278.

109. Adinugraha, M. P., Marseno, D. W., \& Haryadi, P. (2005). Synthesis and characterization of sodium carboxymethylcellulose from cavendish banana pseudo stem (Musa cavendishii LAMBERT). Carbohydrate Polymers, 62(2), 164-169. http:/ dx.doi.org/10.1016/j.carbpol.2005.07.019.

110. Luz, S. M., Gonçalves, A. R., \& Del'Arco, A. P. Jr (2007). Mechanical behavior and microstructural analysis of sugarcane bagasse fibers reinforced polypropylene composites. Composites Part A: Applied Science and Manufacturing, 38(6), 1455-1461. http://dx.doi.org/10.1016/j.compositesa.2007.01.014.

111. Monteiro, S. N., Aquino, R. C. M. P., Lopes, P. D., Carvalho, E. A., \& D`Almeida, J. R. (2006). Comportamento mecânico e características estruturais de compósitos poliméricos reforçados com fibras contínuas e alinhadas de caruará. Revista Matéria, 11(3), 197-203.

112. Mohan Rao, K. M., \& Mohana Rao, K. (2007). Extraction and tensile properties of natural fibres: vakka, date and bamboo. Composite Structures, 77, 288-295.

113. Albertini, S., Do Carmo, L. F., \& Prado Filho, L. G. (2007). Utilização de serragem e bagaço de cana-de-açúcar para adsorção de cádmio. Ciência e Tecnologia de Alimentos, 27(1), 113118. http://dx.doi.org/10.1590/S0101-20612007000100020.

114. Sapuan, S. M., Leenie, A., Harimi, M., \& Beng, Y. K. (2006). Mechanical properties of woven banana fibre reinforced epoxy composites. Materials \& Design, 27(8), 689-693. http://dx.doi.org/10.1016/j.matdes.2004.12.016.

115. Bilba, K., Arsene, M. A., \& Ouensanga, A. (2007). Study of banana and coconut fibers botanical composition, thermal degradation and textural observations. Bioresource Technology, 98(1), 58-68. http://dx.doi.org/10.1016/j.biortech.2005.11.030. PMid:16442281

116. Mano, B., Araújo, J. R., Spinacé, M. A. S., \& De Paoli, M. A. (2010). Polyolefin composites with curaua fibres: effect of the processing conditions on mechanical properties, morphology and fibres dimensions. Composites Science and Technology, 70(1), 29-35. http://dx.doi.org/10.1016/j. compscitech.2009.09.002.

117. Moigne, N. L., Oever, M., \& Budtova, T. (2011). A statistical analysis of fibre size and shape distribution after compounding in composites reinforced by natural fibres. Composites. Part A, Applied Science and Manufacturing, 42(10), 1542-1550. http://dx.doi.org/10.1016/j.compositesa.2011.07.012.

118. John, M. J., \& Anandjiwala, R. D. (2009). Chemical modification of flax reinforced polypropylene composites. Composites Part A: Applied Science and Manufacturing, 40(4), 442-448.

119. Yan, Z. L., Wang, H., Lau, K. T., Pather, S., Zhang, J. C., Lin, G., \& Ding, Y. (2013). Reinforcement of polypropylene with hemp fibres. Composites Part B: Engineering, 46, 221-226. http://dx.doi.org/10.1016/j.compositesb.2012.09.027.

120. Acha, B. A., Reboredo, M. M., \& Marcovich, N. E. (2007). Creep and dynamic mechanical behavior of PP-jute composites: effect of the interfacial adhesion. Composites Part A: Applied Science and Manufacturing, 38(6), 1507-1516. http://dx.doi. org/10.1016/j.compositesa.2007.01.003.

121. Kaewkuk, S., Sutapun, W., \& Jarukumjorn, K. (2013). Effects of interfacial modification and fiber content on physical properties of sisal fiber/polypropylene composites. Composites Part B: Engineering, 45(1), 544-549. http://dx.doi. org/10.1016/j.compositesb.2012.07.036.

122. Cerqueira, E. F., Baptista, C. A. R. P., \& Mulinari, D. R. (2011). Mechanical behaviour of polypropylene reinforced sugarcane bagasse fibers composites. Procedia Engineering, 10, 2046-2051. http://dx.doi.org/10.1016/j.proeng.2011.04.339. 
123. Ibrahim, M. M., Dufresne, A., El-Zawawy, W. K., \& Agblevor, F. A. (2010). Banana fibers and microfibrils as lignocellulosic reinforcements in polymer composites. Carbohydrate Polymers, 81(4), 811-819. http://dx.doi.org/10.1016/j.carbpol.2010.03.057.

124. Brahmakumar, M., Pavithran, C., \& Pillai, R. M. (2005). Coconut fibre reinforced polyethylene composites: effect of natural waxy surface layer of the fibre on fibre/matrix interfacial bonding and strength of composites. Composites Science and Technology, 65(3-4), 563-569. http://dx.doi. org/10.1016/j.compscitech.2004.09.020.

125. Rahman, R., Islam, N., Huque, M., Hamdan, S., \& Ahmed, A. S. (2010). Effect of chemical treatment on Rice Husk (RH) reinforced Polyethylene (PE) composites. BioResources, 5(2), 854-869.

126. Ahmad, E. E. M., \& Luyt, A. S. (2012). Effects of organic peroxide and polymer chain structure on morphology and thermal properties of sisal fibre reinforced polyethylene composites. Composites Part A: Applied Science and Manufacturing, 43(4), 703-710. http://dx.doi.org/10.1016/j. compositesa.2011.12.011.

127. Liu, H., Wu, Q., \& Zhang, Q. (2009b). Preparation and properties of banana fiber-reinforced composites based on high density polyethylene (HDPE)/Nylon-6 blends. Bioresource Technology, 100(23), 6088-6097. http://dx.doi.org/10.1016/j. biortech.2009.05.076. PMid:19574041

128. Adhikary, K. B., Pang, S., \& Staiger, M. P. (2008). Dimensional stability and mechanical behaviour of wood-plastic composites based on recycled and virgin High-Density Polyethylene (HDPE). Composites Part B: Engeneering, 39(5), 807-815. http://dx.doi.org/10.1016/j.compositesb.2007.10.005.

129. Carvalho, K. C. C., Mulinari, D. R., Voorvald, H. J. C., \& Cioffi, M. O. H. (2010). Chemical modification effect on the mechanical properties of HIPS/coconut fiber composites. BioResources, 5(2), 1143-1155.

130. Antich, P., Vázquez, A., Mondragon, I., \& Bernal, C. (2006). Mechanical behavior of high impact polystyrene reinforced with short sisal fibers. Composites Part A: Applied Science and Manufacturing, 37(1), 139-150. http://dx.doi.org/10.1016/j. compositesa.2004.12.002.

131. Benini, K. C. C. C., Cioffi, M. O. H., \& Voorwald, H. J. C. (2011). Mechanical properties of HIPS/sugarcane bagasse fiber composites after accelerated weathering. Procedia Engineering, 10, 3254-3259.

132. Wong, K. J., Zahi, S., Low, K. O., \& Lim, C. C. (2010). Fracture characterisation of short bamboo fibre reinforced polyester composites. Materials \& Design, 31(9), 4147-4154. http://dx.doi.org/10.1016/j.matdes.2010.04.029.

133. Sreekumar, P. A., Albert, P., Unnikrishnan, G., Joseph, K., \& Thomas, S. (2008). Mechanical and water sorption studies of ecofriendly banana fiber-reinforced polyester composites fabricated by RTM. Journal of Applied Polymer Science, 109(3), 1547-1555. http://dx.doi.org/10.1002/app.28155.

134. Mariatti, M., Jannah, M., Abu Bakar, A., \& Abdul Khalil, V. J. (2008). Properties of banana and pandanus woven fabric reinforced unsaturated polyester composites. Journal of Composite Materials, 42(9), 931-941. http://dx.doi. org/10.1177/0021998308090452.

135. Monteiro, S. N., Terrones, L. A. H., \& D’Almeida, J. R. M. (2008). Mechanical performance of coir fiber/polyester composites. Polymer Testing, 27(5), 591-595. http://dx.doi. org/10.1016/j.polymertesting.2008.03.003.

136. Monteiro, S. N., Aquino, R. C. M. P., \& Lopes, F. P. D. J. (2008). Performance of curaua fibers in pullout tests. Materials Science, 43(2), 489-493. http://dx.doi.org/10.1007/s10853007-1874-5.
137. Charlet, K., Jernot, J. P., Gomina, M. J., Bizet, L., \& Breard, J. (2010). Mechanical properties of flax fibers and of the derived unidirectional composites. Journal of Composite Materials, 44(24), 2887-2896. http://dx.doi.org/10.1177/0021998310369579.

138. Alix, S., Philippe, E., Bessadok, A., Lebrun, L., Morvan, C., \& Marais, S. (2009). Effect of chemical treatments on water sorption and mechanical properties of flax fibres. Bioresource Technology, 100(20), 4742-4749. http://dx.doi.org/10.1016/j. biortech.2009.04.067. PMid:19477120

139. Sawpan, M. A., Pickering, K. L., \& Fernyhough, A. V. (2011). Effect of fibre treatments on interfacial shear strength of hemp fibre reinforced polylactide and unsaturated polyester composites. Composites Part A: Applied Science and Manufacturing, 42(9), 1189-1196. http://dx.doi.org/10.1016/j. compositesa.2011.05.003.

140. Rouison, D., Sain, M., \& Couturier, M. (2006). Resin transfer molding of hemp fiber composites: optimization of the process and mechanical properties of the materials. Composites Science and Technology, 66(7-8), 895-906. http://dx.doi. org/10.1016/j.compscitech.2005.07.040.

141. Sever, K., Sarikanat, M., Seki, Y., Erkan, G., Erdogan, U. H., \& Erden, S. (2012). Surface treatments of jute fabric: the influence of surface characteristics on jute fabrics and mechanical properties of jute/polyester composites. Industrial Crops and Products, 35(1), 22-30. http://dx.doi.org/10.1016/j. indcrop.2011.05.020.

142. Akil, H. M., Cheng, L. W., Mohd Ishak, Z. A., Abu Bakar, A., \& Abd Rahman, M. A. (2009). Water absorption study on pultruded jute fibre reinforced unsaturated polyester composites. Composites Science and Technology, 69(11-12), 1942-1948. http://dx.doi.org/10.1016/j.compscitech.2009.04.014.

143. Devi, L. U., Bhagawan, S. S., \& Thomas, S. (2011). Dynamic mechanical properties of pineapple leaf fiber polyester composites. Polymer Composites, 32(11), 1741-1750. http:// dx.doi.org/10.1002/pc.21197.

144. Idicula, M., Boudenne, A., Umadevi, L., Ibos, L., Candau, Y., \& Thomas, S. (2006). Thermophysical properties of natural fibre reinforced polyester composites. Composites Science and Technology, 66(15), 2719-2725. http://dx.doi. org/10.1016/j.compscitech.2006.03.007.

145. Sreekumar, P. A., Saiah, R., Saiter, J. M., Leblanc, N., Joseph, K., Unnikrishnan, G., \& Thomas, S. (2009). Dynamic mechanical properties of sisal fiber reinforced polyester composites fabricated by resin transfer molding. Polymer Composites, 30(6), 768-775. http://dx.doi.org/10.1002/pc.20611.

146. Sreekumar, P. A., Thomas, S. P., Saiter, J. M., Joseph, K., Unnikrishnan, G., \& Thomas, S. (2009). Effect of fiber surface modification on the mechanical and water absorption characteristics of sisal/polyester composites fabricated by resin transfer molding. Composites Part A: Applied Science and Manufacturing, 40(11), 1777-1784. http://dx.doi.org/10.1016/j. compositesa.2009.08.013.

147. Rodrigues, E. F., Maia, T. F., \& Mulinari, D. R. (2011). Tensile strength of polyester resin reinforced sugarcane bagasse fibers modified by estherification. Procedia Engineering, 10, 2348-2352. http://dx.doi.org/10.1016/j.proeng.2011.04.387.

148. Merlini, C., Soldi, V., \& Barra, G. M. O. (2011). Influence of fiber surface treatment and length on physico-chemical properties of short random banana fiber-reinforced castor oil polyurethane composites. Polymer Testing, 30(8), 833-840. http://dx.doi.org/10.1016/j.polymertesting.2011.08.008.

149. Mothé, C. G., \& Araújo, C. R. (2000). Properties of polyurethane elastomers and composites by thermal analysis. Thermochimica Acta, 357-358, 321-325. http://dx.doi.org/10.1016/S00406031(00)00403-2. 
150. Bakare, I. O., Okieimen, F. E., Pavithran, C., Abdul Khalil, H. P. S., \& Brahmakumar, M. (2010). Mechanical and thermal properties of sisal fiber-reinforced rubber seed oil-based polyurethane composites. Materials \& Design, 31(9), 42744280. http://dx.doi.org/10.1016/j.matdes.2010.04.013.

151. Milanese, A. C., Cioffi, M. O. H., \& Voorwald, H. J. C. (2011). Mechanical behavior of natural fiber composites. Procedia Engineering., 10, 2022-2027. http://dx.doi.org/10.1016/j. proeng.2011.04.335.

152. Venkateshwaran, N., ElayaPerumal, A., Alavudeen, A., \& Thiruchitrambalam, M. (2011). Mechanical and water absorption behaviour of banana/sisal reinforced hybrid composites. Materials \& Design, 32(7), 4017-4021. http:// dx.doi.org/10.1016/j.matdes.2011.03.002.

153. Biswas, S., Kindo, S., \& Patnaik, A. (2011). Effect of fiber length on mechanical behavior of coir fiber reinforced epoxy composites. Fibers and Polymers, 12(1), 73-78. http://dx.doi. org/10.1007/s12221-011-0073-9.

154. Harish, S., Michael, D. P., Bensely, A., Lal, D. M., \& Rajadurai, A. (2009). Mechanical property evaluation of natural fiber coir composite. Materials Characterization, 60(1), 44-49. http://dx.doi.org/10.1016/j.matchar.2008.07.001.

155. Gohil, P. P., \& Shaikh, A. A. (2011). Cotton-epoxy composites: development and mechanical characterization. Key Engineering Materials, 471-472, 291-296. http://dx.doi.org/10.4028/www. scientific.net/KEM.471-472.291.

156. Gning, P. B., Liang, S., Guillaumat, L., \& Pui, W. J. (2011). Influence of process and test parameters on the mechanical properties of flax/epoxy composites using response surface methodology. Journal of Materials Science, 46(21), 68016811. http://dx.doi.org/10.1007/s10853-011-5639-9.

157. Liu, Q., \& Hughes, M. (2008). The fracture behaviour and toughness of woven flax fibre reinforced epoxy composites. Composites. Part A, Applied Science and Manufacturing, 39(10), 1644-1652. http://dx.doi.org/10.1016/j.compositesa.2008.07.008

158. Buksnowitz, C., Adusumalli, R., Pahler, A., Sixta, H., \& Gindl, W. J. (2010). Acoustical properties of Lyocell, hemp, and flax composites. Journal of Reinforced Plastics and Composites, 29(20), 3149-3154. http://dx.doi.org/10.1177/0731684410367533.

159. Karaduman, Y., \& Onal, L. (2011). Water absorption behavior of carpet waste jute-reinforced polymer composites. Journal of Composite Materials, 45(15), 1559-1571. http://dx.doi. org/10.1177/0021998310385021.

160. Mir, A., Zitoune, R., Collombet, F., \& Bezzazi, B. (2010). Study of mechanical and thermomechanical properties of jute/epoxy composite laminate. Journal of Reinforced Plastics and Composites, 29(11), 1669-1680. http://dx.doi. org/10.1177/0731684409341672.

161. Satapathy, A., Mantry, S., Singh, S. K., \& Patnaik, A. (2010). Processing and characterization of jute-epoxy composites reinforced with $\mathrm{SiC}$ derived from rice husk. Journal of Reinforced Plastics and Composites, 29(18), 2869-2878. http://dx.doi.org/10.1177/0731684409341757.

162. Seki, Y. (2009). Innovative multifunctional siloxane treatment of jute fiber surface and its effect on the mechanical properties of jute/thermoset composites. Materials Science and Engineering A, 508(1-2), 247-252. http://dx.doi.org/10.1016/j. msea.2009.01.043.

163. Lopattananon, N., Payae, Y., \& Seadan, M. (2008). Influence of fiber modification on interfacial adhesion and mechanical properties of pineapple leaf fiber-epoxy composites. Journal of Applied Polymer Science, 110(1), 433-443. http://dx.doi org/10.1002/app.28496.

164. Mohan, T. P., \& Kanny, K. (2011). Water barrier properties of nanoclay filled sisal fibre reinforced epoxy composites.
Composites Part A: Applied Science and Manufacturing, 42(4), 385-393. http://dx.doi.org/10.1016/j.compositesa.2010.12.010.

165. Tragoonwichian, S., Yanumet, N., \& Ishida, H. J. (2007). Effect of fiber surface modification on the mechanical properties of sisal fiber-reinforced benzoxazine/epoxy composites based on aliphatic diamine benzoxazine. Journal of Applied Polymer Science, 106(5), 2925-2935. http://dx.doi.org/10.1002/ app. 25797.

166. Joseph, S., Sreekala, M. S., \& Thomas, S. (2008). Effect of chemical modifications on the thermal stability and degradation of banana fiber and banana fiber-reinforced phenol formaldehyde composites. Journal of Applied Polymer Science, 110(4), 2305-2314. http://dx.doi.org/10.1002/app.27648.

167. Joseph, S., \& Thomas, S. (2008). Electrical properties of banana fiber-reinforced phenol formaldehyde composites. Journal of Applied Polymer Science, 109(1), 256-263. http:// dx.doi.org/10.1002/app.27452.

168. Chauhan, S. R., Patnaik, A., Kaith, B. S., Satapathy, A., \& Dwivedy, M. (2009). Journal of Reinforced Plastics and Composites, 28(16), 1933-1944. http://dx.doi. org/10.1177/0731684407089131.

169. Kalia, S., Kaith, B. S., Sharma, S., \& Bhardwaj, B. (2008). Mechanical properties of flax-g-poly(methyl acrylate) reinforced phenolic composites. Fibers and Polymers, 9(4), 416-422. http://dx.doi.org/10.1007/s12221-008-0067-4.

170. Barreto, A. C. H., Esmeraldo, M. A., Rosa, D. S., Fechine, P. B. A., \& Mazzetto, S. E. (2010). Cardanol biocomposites reinforced with jute fiber: microstructure, biodegradability, and mechanical properties. Polymer Composites, 31(11), 1928-1937. http://dx.doi.org/10.1002/pc.20990.

171. Barreto, A. C. H., Rosa, D. S., Fechine, P. B. A., \& Mazzetto, S. E. (2011). Properties of sisal fibers treated by alkali solution and their application into cardanol-based biocomposites. Composites Part A: Applied Science and Manufacturing, 42(5), 492-500. http://dx.doi.org/10.1016/j.compositesa.2011.01.008.

172. Peng, X., Zhong, L., Ren, J., \& Sun, R. (2010). Laccase and alkali treatments of cellulose fibre: surface lignin and its influences on fibre surface properties and interfacial behaviour of sisal fibre/phenolic resin composites. Composites Part A: Applied Science and Manufacturing, 41(12), 1848-1856. http://dx.doi.org/10.1016/j.compositesa.2010.09.004.

173. Botaro, V. R., Siqueira, G., Megiatto, J. D. Jr, \& Frollini, E. (2010). Sisal fibers treated with $\mathrm{NaOH}$ and benzophenonetetracarboxylic dianhydride as reinforcement of phenolic matrix. Journal of Applied Polymer Science, 115(1), 269-276. http://dx.doi. org/10.1002/app.31113.

174. Zhong, L., Fu, S., Li, F., \& Zhan, H. (2010). Chlorine dioxide treatment of sisal fibre: surface lignin and its influences on fibre surface characteristics and interfacial behaviour of sisal fibre/phenolic resin composites. BioResources, 5(4), 2431-2446.

175. Milanese, A. C., Cioffi, M. O. H., \& Voorwald, H. J. C. (2012a). Flexural behavior of sisal/castor oil-based polyurethane and sisal/phenolic composites. Journal of Materials Research, 15(2), 191-197. http://dx.doi.org/10.1590/S1516-14392012005000019.

176. Nicolai, F. N. P., Botaro, V. R., \& Lins, V. F. C. (2008). Effect of saline degradation on the mechanical properties of vinyl ester matrix composites reinforced with glass and natural fibers. Journal of Applied Polymer Science, 108(4), 2494-2502. http://dx.doi.org/10.1002/app.27909.

177. Argento, A., Kim, W., Lee, E. C., Harris, A. M., \& Mielewski, D. F. (2011). Rate dependencies and energy absorption characteristics of nanoreinforced, biofiber, and microcellular polymer composites. Polymer Composites, 32(9), 1423-1429. http://dx.doi.org/10.1002/pc.21169. 
178. Rassmann, S., Paskaramoorthy, R., \& Reid, R. G. (2011). Effect of resin system on the mechanical properties and water absorption of kenaf fibre reinforced laminates. Materials \& Design, 32(3), 1399-1406. http://dx.doi.org/10.1016/j. matdes.2010.09.006.

179. Taj, S., Munawar, M. A., \& Khan, S. U. (2007). Review: natural fiber-reinforced polymer composites. Proceedings of the Pakistan Academy of Sciences, 44(2), 129-144.

180. Rodríguez, E. S., Stefani, P. M., \& Vázquez, A. (2007). Effects of fibers' alkali treatment on the resin transfer molding processing and mechanical properties of jute--vinylester composites. Journal of Composite Materials, 41(14), 17291741. http://dx.doi.org/10.1177/0021998306069889.

181. Alvarez, V., Rodríguez, E., \& Vázquez, A. J. (2006). Thermal degradation and decomposition of jute/vinylester composites. Journal of Thermal Analysis and Calorimetry, 85(2), 383-389. http://dx.doi.org/10.1007/s10973-005-7102-0.

182. Mohamed, A. R., Sapuan, S. M., Shahjahan, M., \& Khalina, A. (2010). Effects of simple abrasive combing and pretreatments on the properties of Pineapple Leaf Fibers (Palf) and palf-vinyl ester composite adhesion. Polymer-Plastics Technology and Engineering, 49(10), 972-978. http://dx.doi.org/10.1080/03 602559.2010.482072.

183. Song, J. H., Mun, S. D., \& Kim, C. S. (2011). Mechanical properties of sisal natural fiber composites according to strain rate and absorption ratio. Polymer Composites, 32(8), 1174-1180. http://dx.doi.org/10.1002/pc.21136.

184. Kim, H. J. K., \& Seo, D. W. (2006). Effect of water absorption fatigue on mechanical properties of sisal textile-reinforced composites. International Journal of Fatigue, 28(10), 13071314. http://dx.doi.org/10.1016/j.ijfatigue.2006.02.018.

185. Cao, Y., Shibata, S., \& Fukumoto, I. (2006). Mechanical properties of biodegradable composites reinforced with bagasse fibre before and after alkali treatments. Composites Part A: Applied Science and Manufacturing, 37(3), 423-429. http://dx.doi.org/10.1016/j.compositesa.2005.05.045.

186. Guimarães, J. L., Wypych, F., Saul, C. K., Ramos, L. P., \& Satynarayana, K. G. (2010). Studies of the processing and characterization of corn starch and its composites with banana and sugarcane fibers from Brazil. Carbohydrate Polymers, 80(1), 130-138. http://dx.doi.org/10.1016/j.carbpol.2009.11.002.

187. Gomes, A., Matsuo, T., Goda, K., \& Ohgi, J. (2007). Development and effect of alkali treatment on tensile properties of curaua fiber green composites. Composites Part A: Applied Science and Manufacturing, 38(8), 1811-1820. http://dx.doi. org/10.1016/j.compositesa.2007.04.010.

188. Rosa, M. F., Chiou, B. S., Medeiros, E. S., Wood, D. F., Williams, T. G., Mattoso, L. H. C., Orts, W. J., \& Imam, S. H. (2009). Effect of fiber treatments on tensile and thermal properties of starch/ethylene vinyl alcohol copolymers/coir biocomposites. Bioresource Technology, 100(21), 51965202. http://dx.doi.org/10.1016/j.biortech.2009.03.085. PMid: 19560341

189. Kim, J. T., \& Netravali, A. N. (2010). Mercerization of sisal fibers: effect of tension on mechanical properties of sisal fiber and fiber-reinforced composites. Composites Part A: Applied Science and Manufacturing, 41(9), 1245-1252. http://dx.doi. org/10.1016/j.compositesa.2010.05.007.

190. Ferraro, R. M., \& Nanni, A. (2012). Effect of off-white rice husk ash on strength, porosity, conductivity and corrosion resistance of white concrete. Construction \& Building Materials, 31, 220-225. http://dx.doi.org/10.1016/j.conbuildmat.2011.12.010.

191. Deepa, B., Abraham, E., Cherian, B. M., \& Bismarch, A. (2011). Structure, morphology and thermal characteristics of banana nano fibers obtained by steam explosion. Bioresource Technology, 102(2), 1988-1997.

192. Huang, Z., Wang, N., Zhang, Y., Hu, H., \& Luo, Y. (2012). Effect of mechanical activation pretreatment on the properties of sugarcane bagasse/poly(vinyl chloride) composites. Composites Part A: Applied Science and Manufacturing, 43(1), 114-120. http://dx.doi.org/10.1016/j.compositesa.2011.09.025.

193. Biron, M. (2007). Thermoplastics and thermoplastic composites: technical information for plastics users. Amsterdam: ButterwortHeineman.

194. Callister, W. D., Jr. (2006). Fundamentos da ciência e engenharia de materiais: uma abordagem integrada. Rio de Janeiro: LTC.

195. Mark, J. E. (1999). Polymer data handbook. New York: Oxford University Press.

196. Pilato, L. (2010). Phenolic resins: a century of progress. New York: Springer. http://dx.doi.org/10.1007/978-3-642-04714-5.

197. Gupta, N., Ye, R., \& Porfiri, M. (2010). Comparison of tensile and compressive characteristics of vinyl ester/ glass microballoon syntactic foams. Composites Part B: Engineering, 41(3), 236-245. http://dx.doi.org/10.1016/j. compositesb.2009.07.004.

198. Silva, R. V., Ueki, M. M., Spinelli, D., Bose Filho, W. W., \& Tarpani, J. R. (2010). Thermal, mechanical, and hygroscopic behavior of sisal fiber/polyurethane resin-based composites. Journal of Reinforced Plastics and Composites, 29(9), 13991417. http://dx.doi.org/10.1177/0731684409102986.

199. Canevarolo, S. V., Jr. (2004). Ciência dos polímeros: um texto básico para tecnólogos e engenheiros (1st rep.). São Paulo: Artliber Editora.

200. Borsoi, C., Scienza, L. C., Zattera, A. J., \& Angrizani, C. C. (2011). Obtenção e caracterização de compósitos utilizando poliestireno como matriz e resíduos de fibras de algodão da indústria têxtil como reforço. Polímeros, 21(4), 271-279. http://dx.doi.org/10.1590/S0104-14282011005000055.

201. Grizzo, L. H., Hage, E. H., Jr., \& Laurini, R. V. (2011). Desenvolvimento de $\mathrm{PVC}$ reforçado com fibras de vidro longas para fabricação de produtos moldados. Polímeros: Ciência e Tecnologia, 21(5), 369-375. http://dx.doi.org/10.1590/ S0104-14282011005000065.

202. Silva, R. V., Spinelli, D., Bose Filho, W. W., Claro Neto, S., Chierice, G. O., \& Tarpani, J. R. (2006). Fracture toughness of natural fibers/castor oil polyurethane composites. Composites Science and Technology, 66(10), 1328-1335. http://dx.doi. org/10.1016/j.compscitech.2005.10.012.

203. Melo, B. N., \& Pasa, V. M. D. (2003). Composites based on eucalyptus tar pitch/castor oil polyurethane and short sisal fibers. Journal of Applied Polymer Science, 89(14), 37973802. http://dx.doi.org/10.1002/app.12424.

204. Miléo, P. C., Mulinari, D. R., Baptista, C. A. R. P., Rocha, G. J. M., \& Gonçalves, A. R. (2011). Mechanical behaviour of polyurethane from castor oil reinforced sugarcane straw cellulose composites. Procedia Engineering, 10, 2068-2073. http://dx.doi.org/10.1016/j.proeng.2011.04.342.

Received: Apr. 07, 2014

Revised: Jun. 10, 2014

Accepted: Aug. 19, 2014 